\title{
G9a Histone Methyltransferase Activity in Retinal Progenitors Is Essential for Proper Differentiation and Survival of Mouse Retinal Cells
}

\author{
Kimiko Katoh, ${ }^{1,2,3}$ Ryoji Yamazaki, ${ }^{1,2,3,4}$ Akishi Onishi, ${ }^{3}$ Rikako Sanuki, ${ }^{1,2,3}$ and Takahisa Furukawa ${ }^{1,2,3}$ \\ ${ }^{1}$ Laboratory for Molecular and Developmental Biology, Institute for Protein Research, Osaka University, ${ }^{2}$ Japan Science and Technology Agency, Core \\ Research for Evolutional Science and Technology, Suita, Osaka, 565-0871, Japan, ${ }^{3}$ Department of Developmental Biology, Osaka Bioscience Institute, Suita, \\ Osaka, 565-0874, Japan, and ${ }^{4}$ Osaka City University Graduate School of Medicine, Abeno-ku, Osaka, 545-8585, Japan
}

In vertebrate retinal development, various transcription factors are known to execute essential activities in gene regulation. Although epigenetic modification is considered to play a pivotal role in retinal development, the exact in vivo role of epigenetic regulation is still poorly understood. We observed that G9a histone methyltransferase, which methylates histone H3 at lysine 9 (H3K9), is substantially expressed in the mouse retina throughout development. To address in vivo G9a function in the mouse retina, we ablated G9a in retinal progenitor cells by conditional gene knock-out ( $G 9 a D k k 3 \mathrm{CKO}$ ). The G9a Dkk3 CKO retina exhibited severe morphological defects, including photoreceptor rosette formation, a partial loss of the outer nuclear layer, elevated cell death, and persistent cell proliferation. Progenitor cellrelated genes, including several cyclins, Hes1, Chx10, and Lhx2, are methylated on histone H3K9 in the wild-type retina, but they were defective in H3K9 methylation and improperly upregulated at late developmental stages in the G9a Dkk3 CKO retina. Notably, conditional depletion of G9a in postmitotic photoreceptor precursors $(\mathrm{G} 9 \mathrm{a} \mathrm{Cr} x \mathrm{CKO}$ ) led to the development of an almost normal retina, indicating that $\mathrm{G} 9 \mathrm{a}$ activity mainly in retinal progenitor cells, but not in photoreceptor precursors, is essential for normal terminal differentiation of and survival of the retina. Our results suggest that proper epigenetic marks in progenitor cells are important for subsequent appropriate terminal differentiation and survival of retinal cells by repressing progenitor cell-related genes in differentiating retinal cells.

\section{Introduction}

In vertebrate retinal development, six types of neurons and glial cells (photoreceptors, horizontal cells, bipolar cells, amacrine cells, ganglion cells, and Müller glial cells) are generated from common multipotent progenitor cells (Cepko, 1996). In this process, the gene expression programs controlling retinal development need to be precisely controlled by activating the expression of proper genes and repressing the expression of improper genes. Epigenetic regulation, including DNA methylation and modifications of the histone tail, contributes to the regulation of gene expression during development in coordination with transcrip-

Received April 15, 2012; revised Sept. 23, 2012; accepted 0ct. 15, 2012.

Author contributions: K.K. and T.F. designed research; K.K., R.Y., and R.S. performed research; A.O. and T.F. contributed unpublished reagents/analytic tools; K.K., R.Y., A.O., and T.F. analyzed data; K.K., R.S., and T.F. wrote the paper.

This work was supported by Core Research for Evolutional Science and Technology from the Japan Science and Technology Agency, a grant from Grant-in-Aid for Scientific Research (B), Young Scientists (B) from the Ministry of Education, Culture, Sports, and Technology of Japan, the Mitsubishi Foundation, the Takeda Science Foundation, the Daiichi-Sankyo Foundation of Life Science, the Japanese Retinitis Pigmentosa Society Foundation, the Japan Foundation for Applied Enzymology, and the Research Foundation for Opto-Science and Technology. We thank Drs. Yoichi Shinkai and Makoto Tachibana for G9a $a^{\text {flox }}$ mice and M. Kadowaki, A. Tani, T. Tsujii, A. Ishimaru, Y. Saioka, H. Abe, and S. Kennedy for technical assistance.

The authors declare no competing financial interests.

Correspondence should be addressed to Takahisa Furukawa, Laboratory for Molecular and Developmental Biology, Institute for Protein Research, Osaka University, 3-2 Yamadaoka, Suita, Osaka, 565-0871, Japan. E-mail: takahisa.furukawa@protein.osaka-u.ac.jp.

DOI:10.1523/JNEUROSCI.1869-12.2012

Copyright $\odot 2012$ the authors $\quad 0270-6474 / 12 / 3217658-13 \$ 15.00 / 0$ tion factors (Reik, 2007). Certain epigenetic modifications produce a persistent change in gene expression in the absence of the original signal that caused them and help to stabilize the differentiated state of a cell in the long term (Ptashne, 2007; Berger et al., 2009; Mohn and Schübeler, 2009). DNA methylation and methylation of histones, especially at histone $\mathrm{H} 3$ at lysine 9 (H3K9), are well known marks associated with stable gene repression. Interestingly, recent studies reported genome-wide association of $\mathrm{H} 3 \mathrm{~K} 9$ dimethylation (H3K9me2) with a differentiation state (Wen et al., 2009; Peric-Hupkes et al., 2010; McDonald et al., 2011). G9a is an enzyme that preferentially produces H3K9me2 (Tachibana et al., 2002; Peters et al., 2003; Rice et al., 2003). The G9a inhibitor BIX-01294 [N-(1-benzylpiperidin-4-yl)-6,7-dimethoxy-2-(4-methyl-1, 4-diazepan-1-yl)quinazolin-4-amine] facilitates the reactivation of pluripotency genes and enhances somatic cell reprogramming (Kubicek et al., 2007; Shi et al., 2008). Therefore, G9a seems to guarantee the differentiated state for a long time. In fact, in mouse adult neurons, G9a regulates brain function through maintenance of the transcriptional homeostasis and is likely to protect the expression of improper genes, including nonneuronal and neuronal progenitor-related genes (Schaefer et al., 2009). In addition, G9a also functions in cell differentiation. Studies of $G 9 a$-deficient mice demonstrated that euchromatic H3K9me2 mediated by G9a is required for normal early embryogenesis and that G9a-deficient mice displayed severe growth retardation and early lethality (Tachibana et al., 2002). T-cell and 
Table 1. Primer sequences

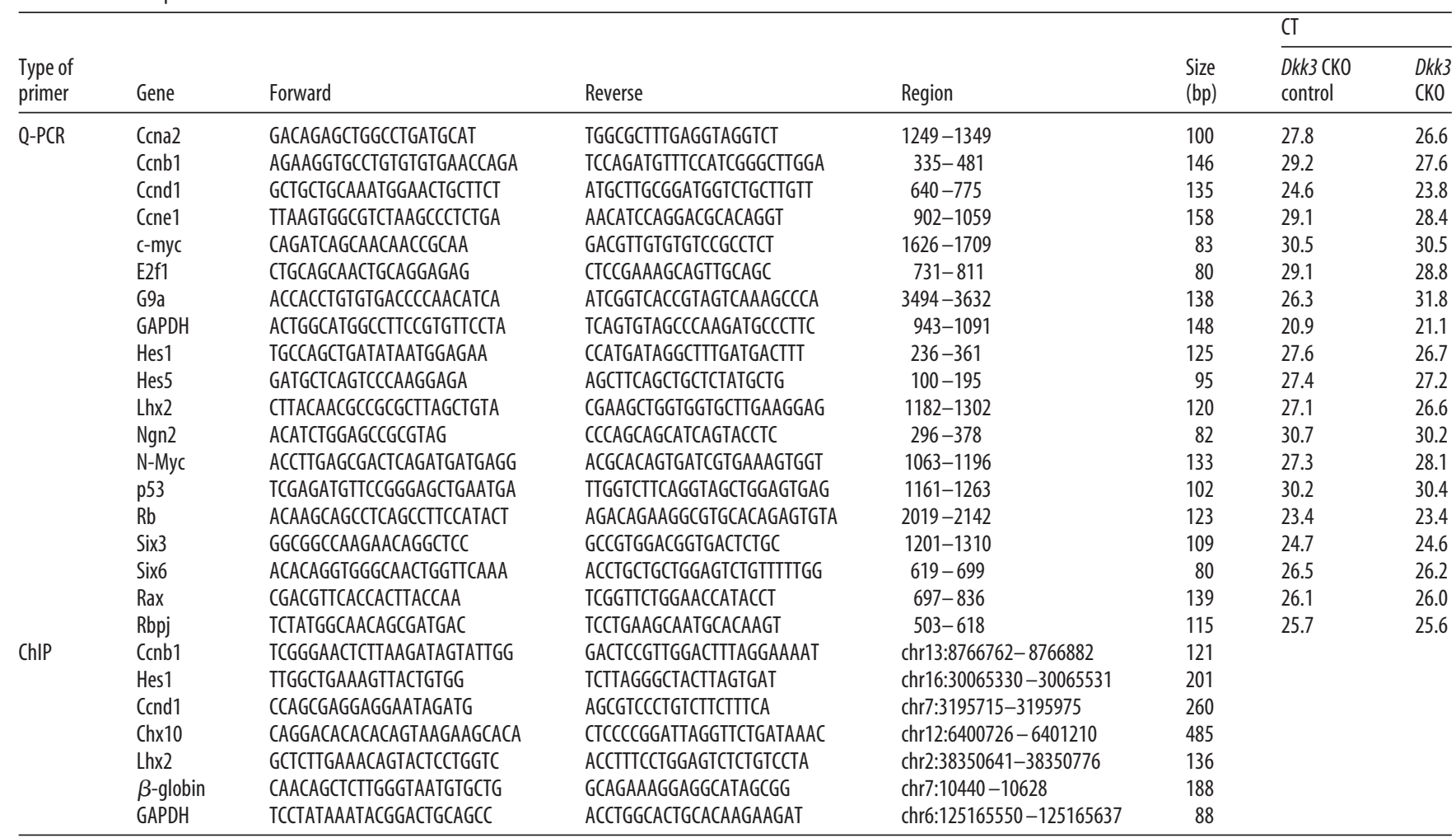

Forward and reverse primer sequences used for RT-PCR and ChIP analyses. The position in the gene to be amplified by PCR, the size of the PCR product, and Ct values are shown.

B-cell maturation are perturbed in T-cell- and B-cell-specific G9a conditional knock-out (CKO) mice, respectively (Thomas et al., 2008; Lehnertz et al., 2010). However, precise functional roles of G9a in vivo remain unknown in CNS development, including retinal development.

To clarify the role of G9a during retinal development, we generated G9a Dkk3 CKO mice in retinal progenitor cells by mating G9a flox mice with Dkk3-Cre mice. G9a Dkk3 CKO mice showed thinner retinal layers and abundant rosette structures. In the G9a Dkk3 CKO retina, cell death was markedly increased through developing stages, and abnormal retinal cell proliferation at postnatal stages was observed. We also observed perturbed development of retinal cells in G9a Dkk3 CKO mice. In contrast, the $G 9 a$ Crx CKO retina showed almost normal development, suggesting that severe abnormalities of the G9a Dkk3 CKO retina were caused mainly by the loss of $\mathrm{H} 3 \mathrm{~K} 9 \mathrm{me} 2$ marks on the promoters of progenitor cell-related genes in retinal progenitor cells. Together, our current study suggests that epigenetic regulation by G9a in retinal progenitor cells plays an essential role for proper retinal development by silencing progenitor genes in terminal differentiation.

\section{Materials and Methods}

Generation of G9a CKO mice. We mated G9 ${ }^{f l o x}$ (Tachibana et al., 2007) mice with Dkk3-Cre-BAC transgenic mice (Sato et al., 2007) and CrxCre transgenic mice (Furukawa et al., 2002; Omori et al., 2012), which express Cre recombinase under the control of the Dkk3 and $2 \mathrm{~kb} C r x$ promoter, respectively. All procedures conformed to the Association for Research in Vision and Ophthalmology Statement for the Use of Animals in Ophthalmic and Vision Research, and these procedures were approved by the Institutional Safety Committee on Recombinant DNA Experiments and the Animal Research Committee of Osaka Bioscience Institute. Mice were housed in a temperature-controlled room with a
$12 \mathrm{~h}$ light/dark cycle. Fresh water and rodent diet were available ad libitum.

Histology and immunohistochemistry. We immunolabeled retinal cryosections as described previously (Katoh et al., 2010). Briefly, embryonic mouse heads and eye cups were fixed in $4 \%$ paraformaldehyde in PBS for either $30 \mathrm{~min}$ or $3 \mathrm{~h}$. The samples were cryoprotected, embedded, frozen, and sectioned ( $20 \mu \mathrm{m}$ thick). Slides were incubated with blocking solution (4\% normal donkey serum and $0.1 \%$ Triton X-100 in PBS) for $1 \mathrm{~h}$ and then with the primary antibodies for $3 \mathrm{~h}$ at room temperature or overnight at $4^{\circ} \mathrm{C}$. Slides were washed with PBS three times for $10 \mathrm{~min}$ each time and incubated with the secondary antibodies for $1 \mathrm{~h}$ at room temperature. The specimens were observed under a laser confocal microscope (LSM700; Carl Zeiss). We used the following primary antibodies: mouse monoclonal antibodies specific to Brn3a (1:100; Millipore Bioscience Research Reagents), Calbindin (1:200; Zymed), Cyclin D3 (1:100; Cell Signaling Technology), G9a (1:100; Perseus Proteomics), Lim1 (1: 100; Developmental Studies Hybridoma Bank), Pax6 (1:200; Developmental Studies Hybridoma Bank), proliferating cell nuclear antigen (PCNA) (1:500; Dako), Rhodopsin (RET-P1) (1:5000; Sigma), and S100 $\beta$ (1:1000; Sigma); rabbit polyclonal antibodies to active caspase 3 (1:200; Promega), Calbindin (1:1000; Calbiochem), Chx10 (1:100) (Koike et al., 2007), Crx (1:300) (Katoh et al., 2010), glial fibrillary acidic protein (GFAP) (1:1000; Sigma), M-opsin (1:300; Millipore Bioscience Research Reagents), phospho-Histone H3 (pH3) (1:100; Millipore), Prox1 (1:2000; Millipore Bioscience Research Reagents), Recoverin (1: 1000; Millipore Bioscience Research Reagents), and Sox9 (1:750; Millipore); goat polyclonal antibodies to Brn3b (1:100; Santa Cruz Biotechnology), Lhx2 (1:1000; Santa Cruz Biotechnology), Otx2 (1:500; R\&D Systems), and S-opsin (1:500; Santa Cruz Biotechnology); and a guinea pig polyclonal antibody to $\operatorname{Thr} \beta 2$ (1:100; Wako) (Sanuki et al., 2011). We also used Alexa Fluor 488 phalloidin (1:3000; Invitrogen). For secondary antibodies, we used Alexa Fluor 488 and Alexa Fluor 568 (1:400; Invitrogen). Counterstaining with the fluorescent nuclear dye $4^{\prime}$, 6-diamidino-2- phenylindole dihydrochloride (1:1000; Sigma) was performed. Terminal deoxynucleotidyl transferase dUTP nick end labeling 

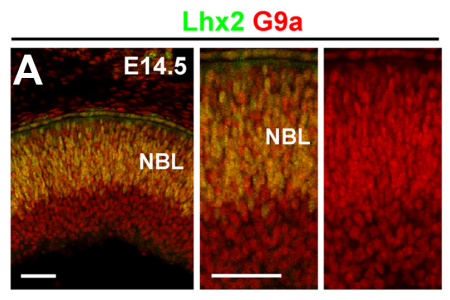

Crx G9a
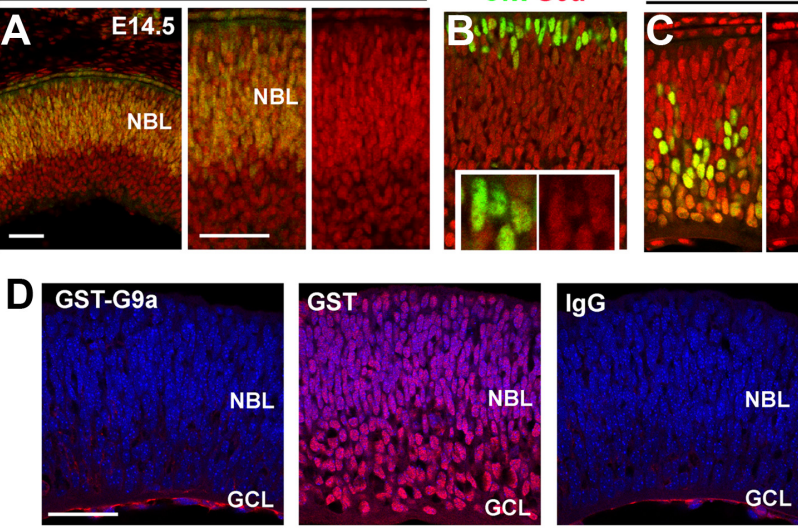
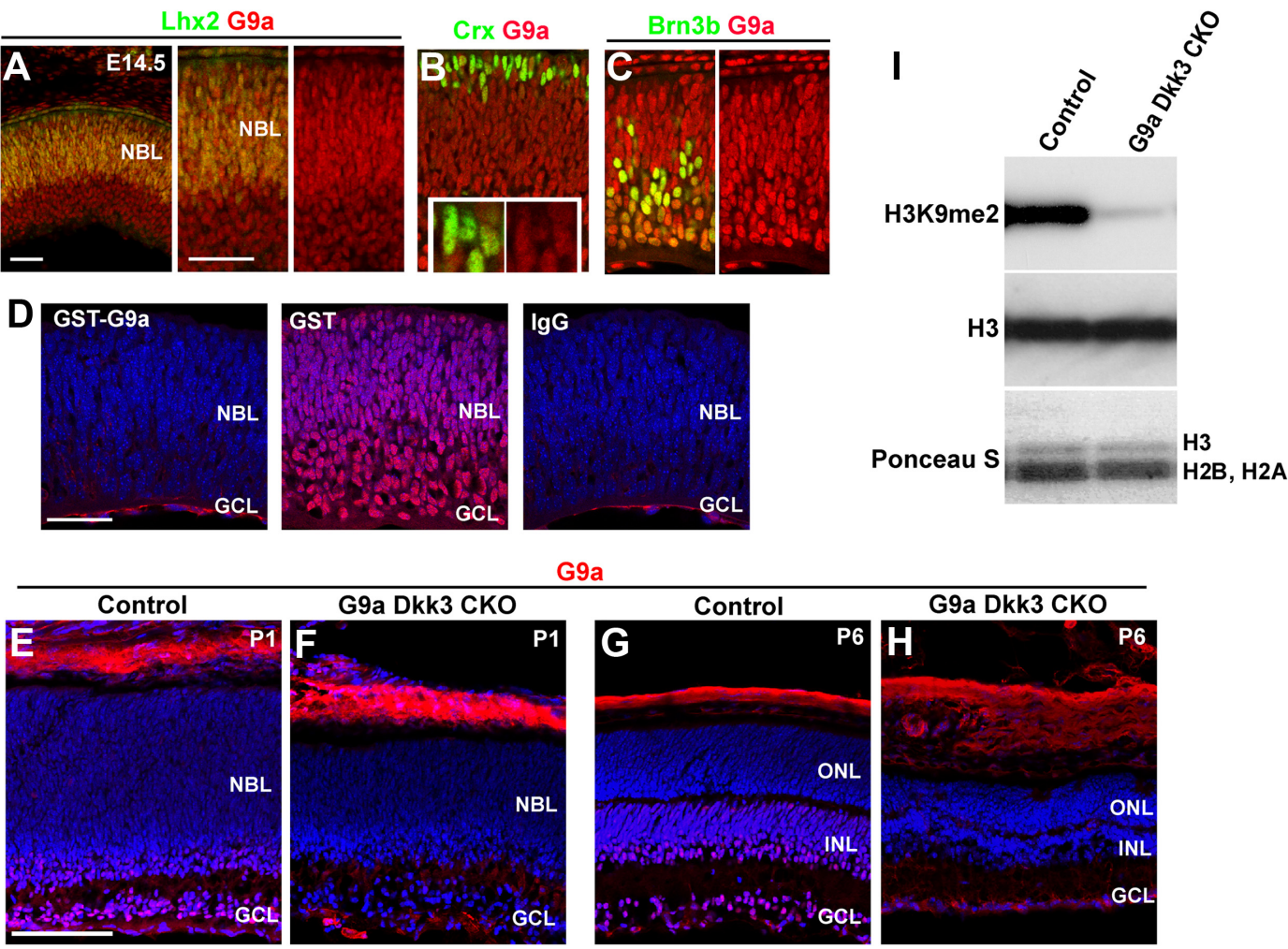

G9a
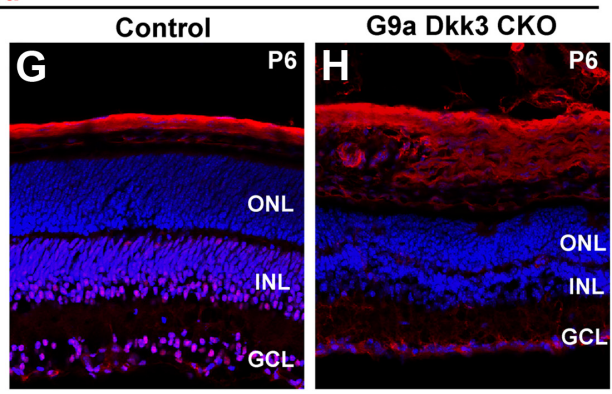

Figure 1. Targeted disruption of G9a caused severe defects in retinal development. $\boldsymbol{A}-\boldsymbol{C}$, Expression of G9a, Lhx2 (retinal progenitor cells, $\boldsymbol{A}$ ), Crx (photoreceptor precursor cells, $\boldsymbol{B}$ ), and Brn3b (ganglion cells, $C$ ) in the E14.5 WT retina. G9a is expressed in all retinal cells at this stage. The inset shows (rx- and G9a-double-positive cells at high magnification. $\boldsymbol{D}$, Immunodepletion assay of G9a. The anti-G9a antibody immunodepleted by GST-G9a (left) did not show a significant signal by immunostaining, nor did the lgG control (right). In contrast, the anti-G9a antibody immunodepleted by GST showed strong signals. $\boldsymbol{E}-\boldsymbol{H}$, Expression of G9a in the control $(\boldsymbol{E}, \boldsymbol{G})$ and $G 9 a$ Dkk3 CKO retinas $(\boldsymbol{F}, \boldsymbol{H})$ at $P 1(\boldsymbol{E}, \boldsymbol{F})$ and $P 6(\boldsymbol{G}, \boldsymbol{H})$. G9a (red) signal was negative in the $G 9 a$ Dkk3 $C K 0$ retina. Blue staining is a nuclear dye. I, Western blot analysis of P7 histone extracts from the control and the G9a Dkk3 CKO retinas with an anti-H3K9me2 antibody. The amount of histone H3 was precalibrated with anti-H3 antibody and Ponceau S staining. Scale bars, $100 \mu \mathrm{m}$.

(TUNEL) assays were performed using the Click-iT EdU Imaging Kits (Invitrogen) according to the instructions of the manufacturer.

Immunodepletion. For the GST-G9a construct, we used a G9a_14115_FB primer (5' -ATGGGATCCGGG GAGGCCCCCGCTGAGATG$3^{\prime}$ ) and a G9a_14-115_RX+Stop primer (5'-ATGCTCGAGTCAAGA GGGGAACGACTTTGTGGCA-3'). Cloned G9a was inserted into the BamHI/XhoI sites of pGEX 4T-1 vector. To immunodeplete the G9a antibody, GST-G9a (G9a amino acid residues 14-115) protein and GST protein alone were isolated with glutathione-Sepharose beads (GE Healthcare) from $500 \mathrm{ml}$ Escherichia coli (BL21 DL3) cultures. The beads with the absorbed GST proteins were resuspended in $500 \mu \mathrm{l}$ of PBS, and $5 \mu \mathrm{l}$ of anti-G9a antibody was added. The same amount of control rabbit IgG was used for mock depletion. The mixtures were incubated at $4^{\circ} \mathrm{C}$ overnight. After incubation, the beads were removed by centrifugation. For immunostaining, we added the supernatants into normal donkey serum (final concentration, 4\%) and Triton X-100 (final concentration, 0.1\%). For another negative control, mouse IgG was used for immunostaining.

Western blot analysis for histone tail modifications. Acid-extracted histones were prepared from postnatal day 7 (P7) mouse retinas as described previously (Cheung et al., 2000). Briefly, retinas were lysed in $100 \mathrm{~mm}$ Tris, pH 7.6, $150 \mathrm{~mm} \mathrm{NaCl}, 1.5 \mathrm{~mm} \mathrm{MgCl}_{2}, 0.65 \% \mathrm{NP}-40$, and $1 \times$ Complete Protease Inhibitor Cocktail (Roche). Nuclei pelleted from the lysis buffer were extracted with $0.4 \mathrm{~N} \mathrm{H}_{2} \mathrm{SO}_{4}$, and acid-soluble histones were precipitated with $20 \%$ trichloroacetic acid. Samples were resolved by SDS-PAGE gels and transferred to PVDF membranes for Western blotting. The amount of histone $\mathrm{H} 3$ was precalibrated with an anti-H3 antibody (Active Motif) and Ponceau S (Sigma) staining. Covalent modification status of $\mathrm{H} 3$ tails was analyzed with an anti-H3K9me2 antibody (Abcam). H3K9me2 signal intensities were normalized to the control signal.

Microarray analysis. Mouse retinas were dissected at P6. Total retinal RNA (500 ng) was isolated using TRIzol (Invitrogen) and processed with the wild-type (WT) expression kit (Ambion) according to the instruc- tions of the manufacturer. Biotin-labeled cRNA was prepared using GeneChip WT terminal labeling and controls kit (Affymetrix) and hybridized to the GeneChip mouse gene 1.0 ST array (Affymetrix). The chips were washed, stained with streptavidin-phycoerythrin, and scanned using a GeneChip Scanner 3000 (Affymetrix). Signal intensities were determined using GeneChip Operating Software 1.4. The output file contained the raw signals of the control and G9a Dkk3 CKO retinas and the $\log 2$ ratio representing the fold difference between control and G9a Dkk3 CKO samples. Statistical analysis was performed to determine which genes are differentially expressed in the G9a Dkk3 CKO retina compared with their controls.

Quantitative real-time PCR. Quantitative real-time PCR (Q-PCR) was performed using SYBR Green ER qPCR Super Mix (Invitrogen) and Thermal Cycler Dice Real Time System single MRQ TP870 (Takara) according to the instructions of the manufacturer. Quantification was performed by Thermal Cycler Dice Real Time System software version 2.0 (Takara). PCR reactions were done in triplicate, and the mean value of the threshold cycle $(\mathrm{Ct})$ was calculated. Expression levels of genes were normalized to the expression level of a housekeeping gene, GAPDH. The mean value of each control was set as 1.0. For chromatin immunoprecipitation (ChIP) analysis, we evaluate the data by input signal. The primer sequences are listed in Table 1.

ChIP analysis. We used the ChIP-IT Express kit (Active Motif) for the ChIP analysis. Genomic DNA and nuclear proteins from P4 and adult (3 months old) WT mouse retinas and P4 and P21 control and G9a Dkk3 $\mathrm{CKO}$ mouse retinal cells were fixed with formaldehyde at room temperature for $10 \mathrm{~min}$. Sheared chromatin $(2 \mu \mathrm{g})$ was precleared with protein $\mathrm{G}$ beads before incubation overnight at $4^{\circ} \mathrm{C}$ with $4 \mu \mathrm{g}$ of anti-H3K9me2 (Abcam) or purified rabbit IgG antibody (Santa Cruz Biotechnology). Then elutes were used as templates for RT-PCR or Q-PCR. Percentage input of each binding site was determined by normalizing the $\mathrm{Ct}$ value of the HeK9me2 enriched site in immunoprecipitated DNA with the Ct 

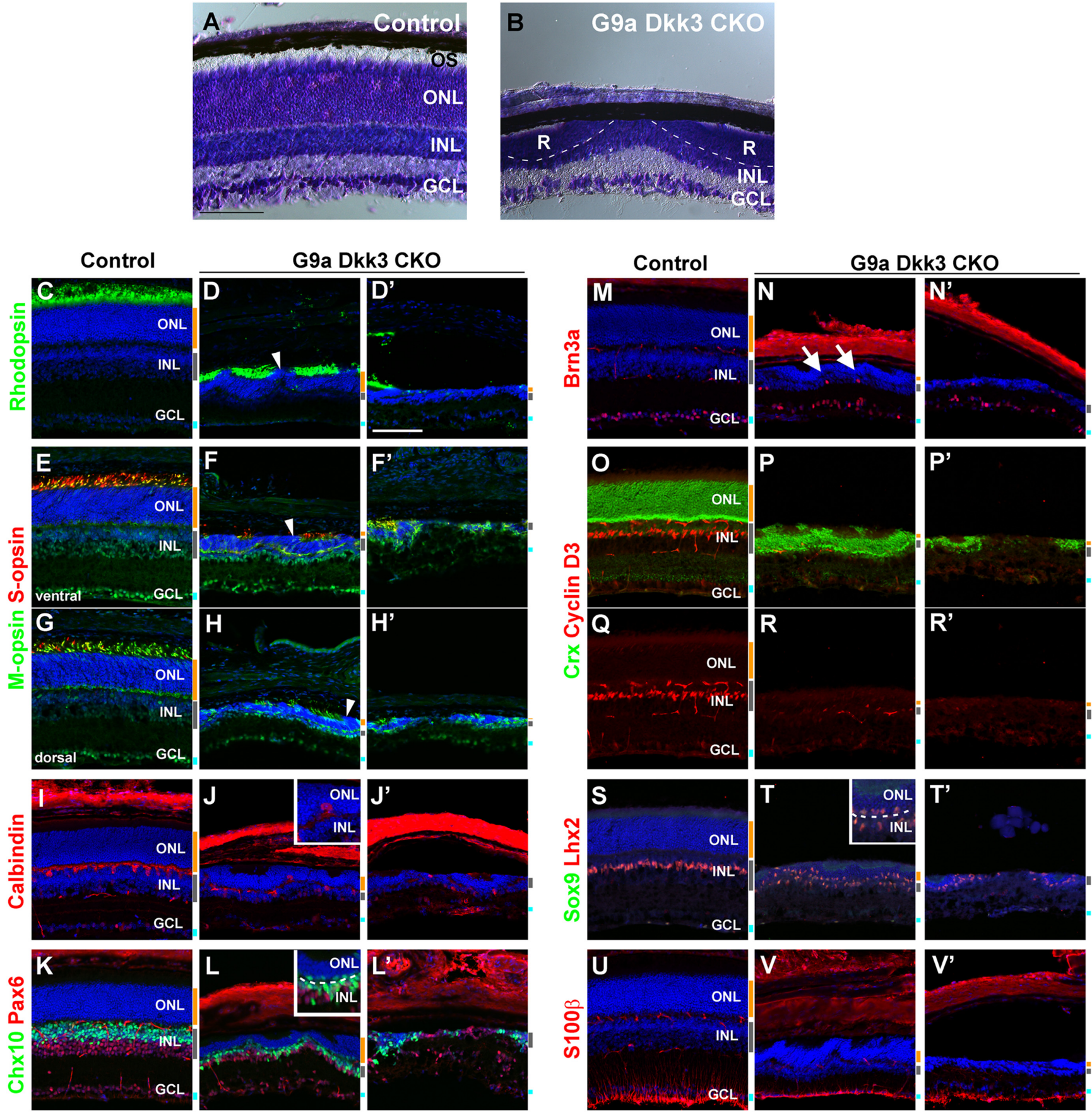

Figure 2. All retinal cell types were affected in the G9a Dkk3 CKO retina. $\boldsymbol{A}-\boldsymbol{B}$, Toluidine blue staining of the retinas of control $(\boldsymbol{A})$ and G9a Dkk3 CKO (B) mice at P14 showed sporadic rosette structures and a partial loss of the ONL in the G9a Dkk3 CKO retina $(\boldsymbol{B})$. Dotted line indicates the border between the INL and ONL. R, Rosette structure. $\left(-V^{\prime}\right.$, P14 retinal sections from control (left) and G9a Dkk3 CKO (middle and right) mice were immunostained with antibodies for rods (Rhodopsin, $\left(-D^{\prime}\right), M$ - and S-cones (M-opsin and S-opsin, $\boldsymbol{E}-\boldsymbol{H}^{\prime}$ ), horizontal cells (Calbindin, $\boldsymbol{I}-\boldsymbol{J}^{\prime}$ ), bipolar

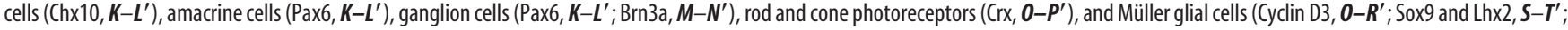
$S 100 \beta, U-V^{\prime}$ ). Blue staining is a nuclear dye. The inset shows aberrant localization of horizontal cells, bipolar cells, and Müller glial cells (2-fold-magnified view). The G9a Dkk3 CKO retinas showed a drastic loss of all retinal cells and severe morphological defects. Arrowheads, Opsin-null photoreceptor cells; dotted lines, the margin of the ONL and INL; arrows, ectopic ganglion cells. Side bars: orange, ONL; gray, INL; cyan, GCL. Scale bars, $100 \mu \mathrm{m}$.

value of that $\mathrm{HeK} 9 \mathrm{me} 2$ enriched site in IgG immunoprecipitation. The primers used for PCR in the ChIP analysis are listed in Table 1.

\section{Results}

Generation of retina-specific $\mathrm{G} 9 a$ CKO mice

To examine the influence of histone modification on mouse retinal development, we searched for chromatin modifying enzymes by investigating our previous microarray datasets from various stages of retinal development (Omori et al., 2011). In this screen, we found that $G 9 a$, a histone modification enzyme, is substantially expressed throughout retinal development. We confirmed G9a protein expression by immunohistochemistry using an antiG9a antibody. At embryonic day 14.5 (E14.5), G9a displayed ubiquitous expression in the developing mouse retina (Fig. 1A). Strong labeling of G9a in Lhx2-positive $\left(\mathrm{Lh} \times 2^{+}\right)$retinal progen- 

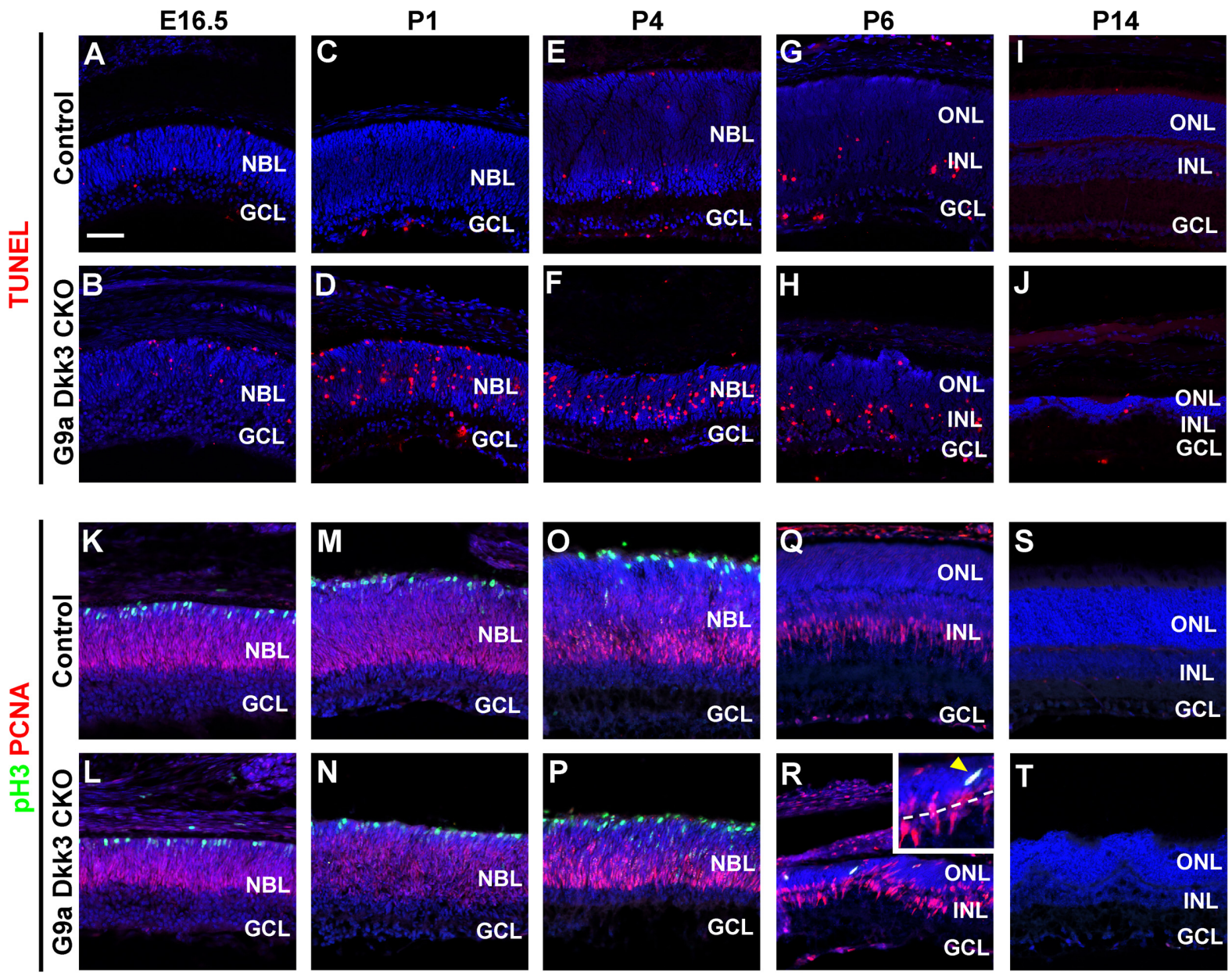

U

V

W
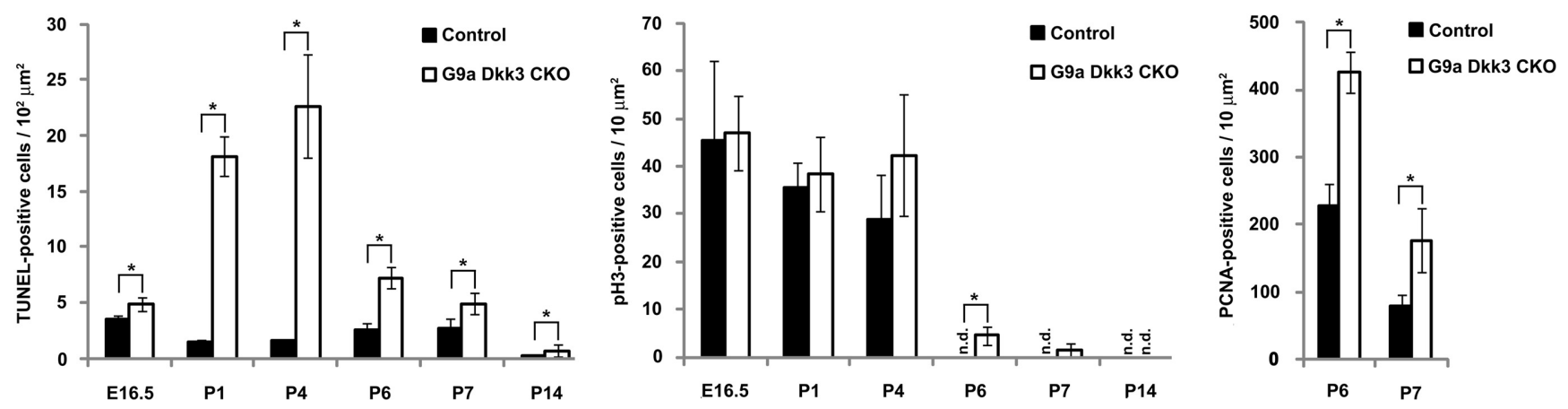

Figure 3. Apoptosis and cell proliferation analysis on the G9a Dkk3 CKO retina. $A-T$, Eyes isolated from control $(A, C, E, G, I, K, M, O, Q, S)$ and $G 9 a$ Dkk3 CKO $(B, D, F, H, J, L, N, P, R, T)$ mice at different ages were subjected to TUNEL (red, $\boldsymbol{A}-\boldsymbol{J}$ ) and immunostaining with anti-pH3 antibody to detect cells in M-phase (green) and anti-PNCA antibody to detect cells in $S$-phase (red) $(\boldsymbol{K}-\boldsymbol{T})$. The inset shows a high magnification (2-fold) of the stained cells $(\boldsymbol{R})$. Blue staining is a nuclear dye. These experiments were performed at E16.5 $(\boldsymbol{A}, \boldsymbol{B}, \boldsymbol{K}, \mathbf{L}), \mathrm{P} 1(\boldsymbol{C}, \boldsymbol{D}, \boldsymbol{M}, \boldsymbol{N}), \mathrm{P} 4(\boldsymbol{E}, \boldsymbol{F}, \mathbf{O}, \boldsymbol{P}), \mathrm{P} 6(\boldsymbol{G}, \boldsymbol{H}, \mathbf{Q}$, $\boldsymbol{R})$, and P14 $(\boldsymbol{I}, \boldsymbol{J}, \boldsymbol{S}, \boldsymbol{T}) \cdot \boldsymbol{U}-\boldsymbol{W}$, The numbers of TUNEL ${ }^{+}(\boldsymbol{U}), \mathrm{pH}^{+}{ }^{+}(\boldsymbol{V})$, and PCNA ${ }^{+}(\boldsymbol{W})$ cells in the control and G9a Dkk3 CKO retina were counted. ${ }^{*} p<0.03 .5$ Sale bars, $50 \mu \mathrm{m}$. Arrowhead, $\mathrm{pH} 3{ }^{+}$ cells; dotted line, border between the ONL and INL.

itor cells was detected (Fig. 1A). We also observed postmitotic cells expressing G9a (Fig. $1 B, C$ and data not shown). To confirm the specificity of the anti-G9a antibody, we performed an immunodepletion assay. We produced and purified GST-G9a protein, which was used as an antigen to raise an antibody, and the GST protein alone for a control. Depletion of the anti-G9a antibody eliminated the signal in G9a immunostaining on the mouse retina to a similar level as the immunostaining using IgG, although the depletion using the GST control did not affect the G9a im- munostaining signal (Fig. 1D). Therefore, the anti-G9a antibody we used in the current study specifically detects G9a-expressing cells. We detected a strong G9a signal in the ganglion cell layer (GCL) and a weak signal at the inner part of the neuroblastic layer (NBL) in the P1 control retina (Fig. $1 E$ ). In the $\mathrm{P} 6$ control retina, we detected a G9a signal both in the inner nuclear layer (INL) and the GCL (Fig. 1G).

To investigate the in vivo function of G9a in the developing retina, we ablated $G 9 a$ from the developing retina by conditional 

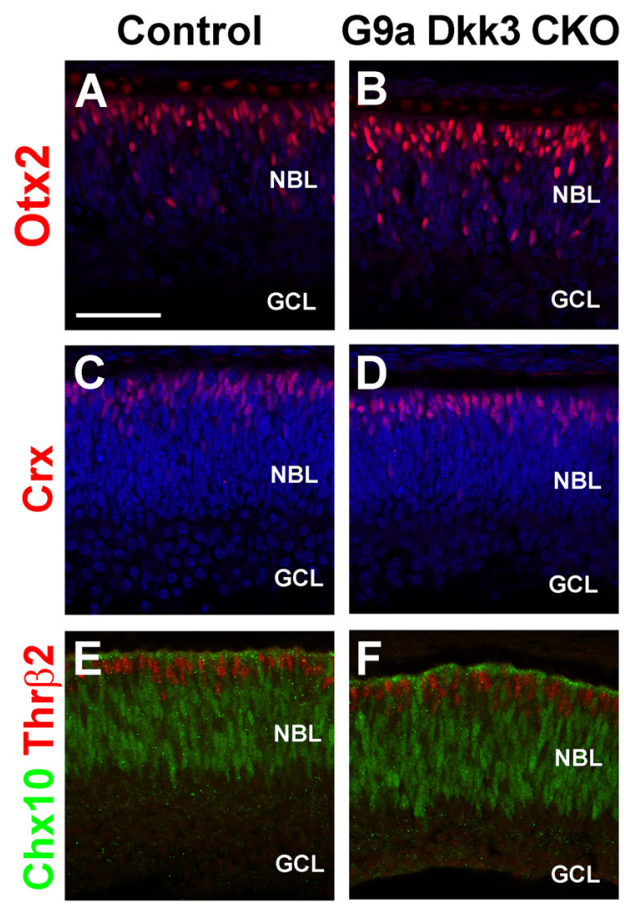
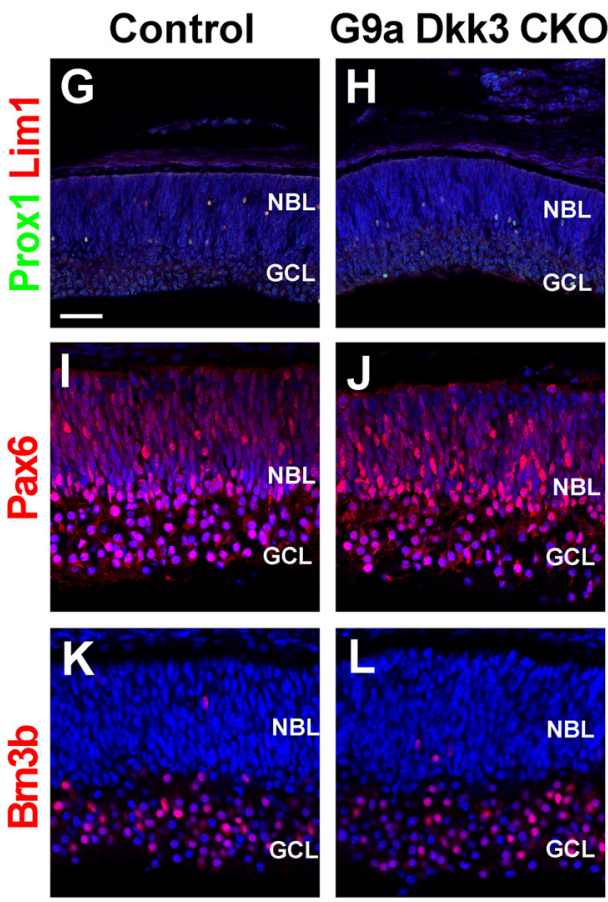

Figure 4. Cell proliferation and early development in the G9a Dkk3 CKO retina. $A-L$, Immunofluorescence staining of the retinas at $E 14.5$. Retinal sections of control $(\boldsymbol{A}, \boldsymbol{C}, \boldsymbol{E}, \boldsymbol{G}, \boldsymbol{I}, \boldsymbol{K})$ and $G 9 a \mathrm{Dkk} 3$ CKO $(\boldsymbol{B}, \boldsymbol{D}, \boldsymbol{F}, \boldsymbol{H}, \boldsymbol{J}, \boldsymbol{L})$ were stained with markers for $0 \mathrm{tx} 2^{+}$and $\mathrm{Crx}{ }^{+}$photoreceptor precursors $(\boldsymbol{A}-\boldsymbol{D}), \operatorname{Thr} \beta 2^{+}$cone photoreceptor precursor cells $(\boldsymbol{E}, \boldsymbol{F}), \operatorname{Prox} 1^{+}$and $\operatorname{Lim} 1^{+}$horizontal cells $(\boldsymbol{G}, \boldsymbol{H})$, $\mathrm{Pax}^{+}{ }^{+}$amacrine cells $(\boldsymbol{I}, \boldsymbol{J}), \mathrm{Brn} 3 \mathrm{~b}^{+}$ganglion cells $(\boldsymbol{K}, \boldsymbol{L})$, and $\mathrm{Chx} 10^{+}$retinal progenitor cells $(\boldsymbol{E}, \boldsymbol{F})$. Blue staining is a nuclear dye. For early generated cell types, cell fate determination was normal in the G9a Dkk3 CKO retina. Scale bars, $50 \mu \mathrm{m}$.

gene targeting. We mated G9a $a^{\text {flox }}$ mice with Dkk3-Cre transgenic mice in which Cre recombinase-mediated recombination occurs in almost all retinal progenitor cells (Sato et al., 2007). We obtained $G 9 a^{\text {flox/flox }} / D k k 3-C r e^{+}$mice as G9a CKO (G9a Dkk3 CKO) mice by mating G9a flox/flox mice with $G 9 a^{+/ f l o x} / D k k 3-C r e^{+}$mice. We analyzed the phenotypes and compared them with those of control mice with the genotype G9a flox/flox $/ D k k 3-C r e^{-}$, which show no abnormal phenotype at P1 and P6 (Fig. 1 E, G). The G9a $D k k 3$ CKO mice were viable and fertile. We confirmed a total loss of G9a mRNA and protein expression in the G9a Dkk3 CKO retina by Q-PCR analysis ( $1.00 \pm 0.04$ vs $0.03 \pm 0.00 ; n=3 ; p<$ $0.0006)$ and immunostaining (Fig. $1 E-H$ ). Moreover, Western blot analysis using an anti-H3K9me2 antibody demonstrated that the H3K9me2 level in the G9a Dkk3 CKO retina was drastically reduced (Fig. 1I). These results suggest that G9a is the major H3K9 dimethyltransferase in the retina.

\section{G9a-deficient retina is severely affected}

We examined the retinal tissue of the G9a Dkk3 CKO and control mouse retinas by toluidine blue staining at $\mathrm{P} 14$, when retinal development is almost complete (Fig. $2 A, B$ ). Notably, in the $G 9 a$ $D k k 3$ CKO retina, retinal layers were substantially thinner than those of the control retina. We observed sporadic rosette structures in the outer nuclear layer (ONL) and a partial loss of the ONL in the G9a Dkk3 CKO retina (Fig. 2A,B). The number and severity of rosettes and ONL-depleted regions varied in each retina. To further confirm the generation of each retinal cell types, we next compared retinal development between the control and G9a Dkk3 CKO retinas at P14 by immunohistochemistry (Fig. $\left.2 C-V^{\prime}\right)$. Although all the cell types were observed in the G9a Dkk3 CKO retina, we observed a significant decrease of cone and rod photoreceptors in the G9a Dkk3 CKO retina (Fig. $2 \mathrm{C}-\mathrm{H}^{\prime}, \mathrm{O}-\mathrm{P}^{\prime}$ ). Interestingly, these signals were partially lost regardless of the existence of photoreceptor cells (Fig. 2D,F,H, arrowhead). Moreover, the number of horizontal cells, bipolar cells, amacrine cells, ganglion cells, and Müller glial cells were also substantially reduced in the G9a Dkk3 CKO retina (Fig. $2 I-V^{\prime}$ ). The numbers of these cells were considerably reduced in the ONL-null area. We also found that some of the Brn3a ${ }^{+}$ganglion cells were located ectopically (Fig. $2 N$, arrows). Notably, some horizontal cells, bipolar cells, and Müller glial cells also penetrated into the ONL (Fig. 2 J, L, T, inset). Moreover, Cyclin D3 ${ }^{+}$Müller glial cells were nearly undetectable (Fig. 2Q- $R^{\prime}$ ), but $\operatorname{Lhx} 2^{+}$, Sox $2^{+}$, and S100 $\beta^{+}$Müller glial cells were present (Fig. $2 S-V^{\prime}$ ). A similar pattern was detected during reactive gliosis (Dyer and Cepko, 2000). Therefore, we immunostained retinas with an anti-GFAP antibody (data not shown), but we could not observe clear signals in either genotype. These results suggest that $G 9 a$ is essential for proper retinal development and appropriate differentiation of all retinal cell types, especially in photoreceptor cells.

Increased cell death of retinal cells and perturbed intensity of progenitor cells

Rosettes have been described previously under various conditions, including loss of $\mathrm{Nrl}$ (Mears et al., 2001), RbpJ (Riesenberg et al., 2009), Ptch1 (Black et al., 2003), Dicer (Damiani et al., 2008), and MAP3K1 (Mongan et al., 2011), and pathological conditions (Lahav et al., 1975, Yuge et al., 1995, Tulvatana et al., 1999). However, we could not detect any significant differences in the gene expressions described above by in situ hybridization or microarray analysis between control and G9a Dkk3 CKO retinas (data not shown). Conversely, in the pathological condition, cell death and/or abnormal proliferation were seen (Lin et al., 2001). Therefore, to investigate the mechanisms underlying the abnormalities observed in the G9a Dkk3 CKO retina, we exam- 


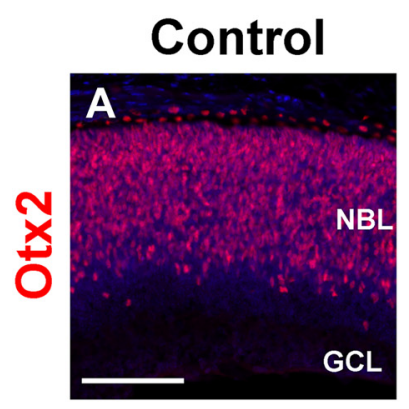

G9a Dkk3 CKO
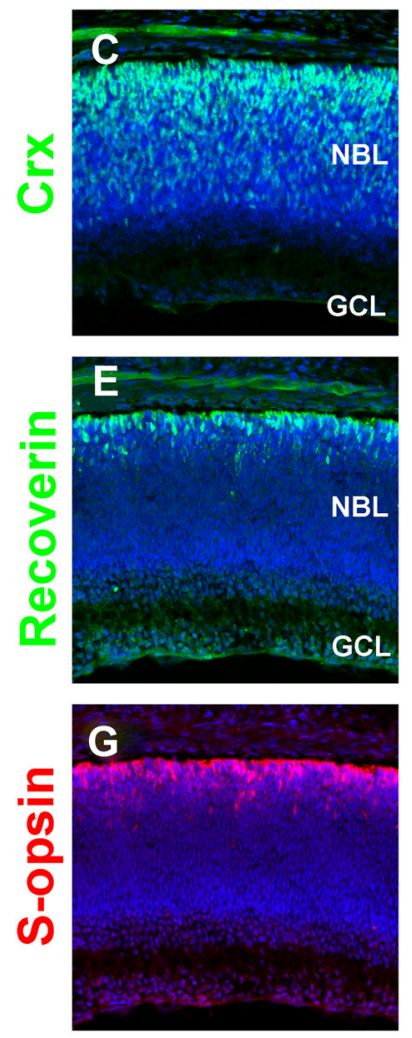
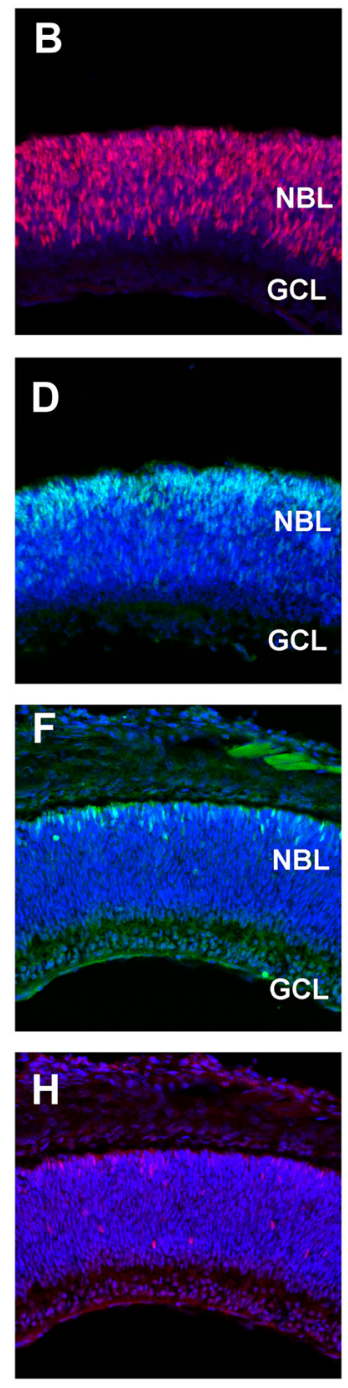

Control
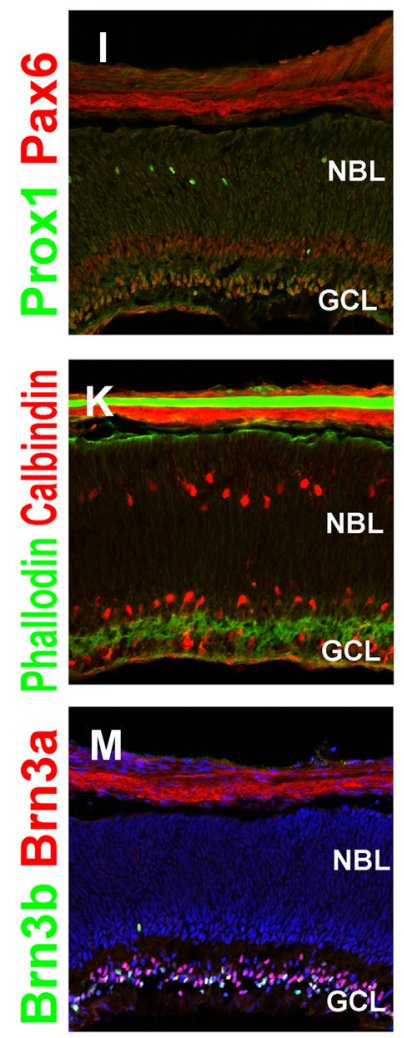

0

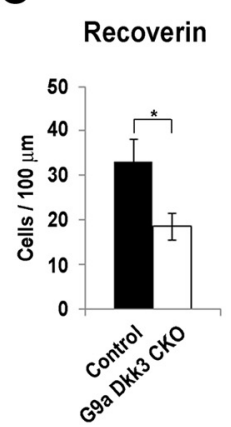

G9a Dkk3 CKO
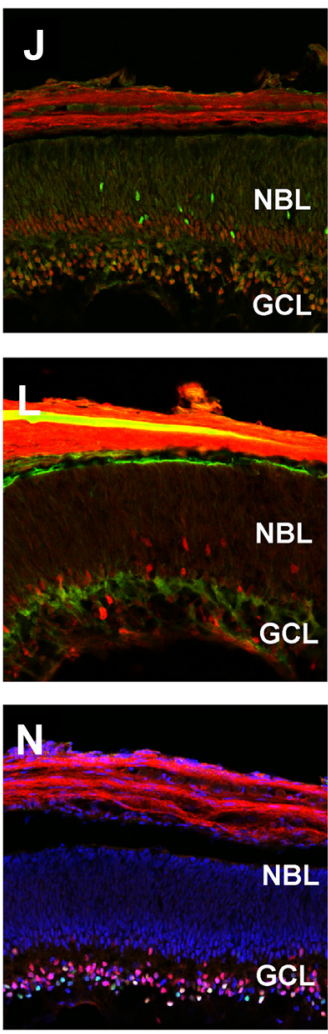

S-opsin

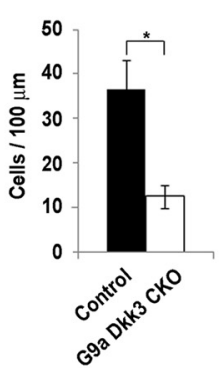

Calbindin (Horizontal)

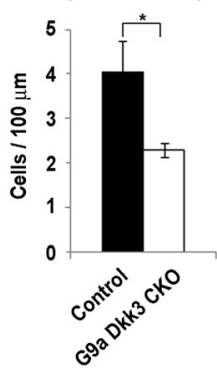

Figure 5. Abnormal development observed in the P1 G9a Dkk3 CKO retina. $A-N$, Retinal sections at $P 1$ of control $(\boldsymbol{A}, \boldsymbol{C}, \boldsymbol{E}, \boldsymbol{G}, \boldsymbol{I}, \boldsymbol{K}, \boldsymbol{M})$ and $G 9 a \mathrm{Dkk} 3 \mathrm{CKO}(\boldsymbol{B}, \boldsymbol{D}, \boldsymbol{F}, \boldsymbol{H}, \boldsymbol{J}, \boldsymbol{L}, \boldsymbol{N})$ mice were stained for

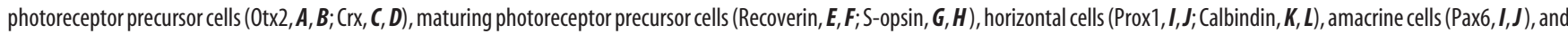
ganglion cells (Brn3a and Brn3b, $\boldsymbol{M}, \boldsymbol{N}$ ). F-actin (Phalloidin, $\boldsymbol{K}, \boldsymbol{L}$ ). F-actin signal showed normal apicobasal polarity of the G9a Dkk3 CKO retina. Blue staining is a nuclear dye. $\mathbf{O}$, Recoverin ${ }^{+}$, $\mathrm{S}$-opsin ${ }^{+}$, Calbindin ${ }^{+}$(horizontal cells) cells were quantified. Statistical analyses were performing by comparing the numbers between control and G9a Dkk3 CKO retinas. ${ }^{*} p<0.03$. Scale bars, $100 \mu \mathrm{m}$.

ined whether the decrease of retinal cells in G9a Dkk3 CKO mice was attributable to cell death and/or cell proliferation defects.

First, we performed TUNEL assays at several developmental stages (E16.5, P1, P4, P6, P7, and P14) (Fig. 3A-J,U). Compared with the control retina, in the G9a Dkk3 CKO retina, cell death increased at E16.5 (Fig. $3 A, B, U$ ), was especially high at $\mathrm{P} 1$ and $\mathrm{P} 4$ (Fig. $3 C-F, U$ ), and still significant at P6 and P7 (Fig. 3G, $H, U$ ). We observed no specific localization of TUNEL ${ }^{+}$cells. These results suggest that $G 9 a$ deletion in the retina results in increased cell death of various cell types but not of any specific cell type.

Next, to examine cell proliferation, we immunostained the control and G9a Dkk3 CKO retinas with anti-pH3 and antiPCNA antibodies to mark M-phase and S-phase, respectively (Fig. $3 K-T, V, W)$. In the retina, progenitor cells at $\mathrm{M}$-phase occur at the apical surface, whereas progenitor cells at S-phase localize at the basal side. At early stages of retinal development, the numbers of $\mathrm{pH}^{+}$cells were similar between both genotypes (Fig. $3 \mathrm{~K}-$ $P, V)$. However, at $\mathrm{P} 6$ and $\mathrm{P} 7, \mathrm{pH} 3{ }^{+}$cells were still detected in the $G 9 a$ Dkk3 CKO retina (Fig. 3Q, $R, V$ ). Simultaneously, the numbers of $\mathrm{PCNA}^{+}$cells also increased (Fig. 3Q, $R, W$ ). Interestingly, ectopic localization of $\mathrm{PCNA}^{+}$cells was observed at the inner part of the ONL at these stages (Fig. $3 R$, arrowhead in inset). These results suggest that developmental delay or spatiotemporal perturbation of retinal progenitor cell proliferation occurs during development in the G9a Dkk3 CKO retina.

Cell fate specification and differentiation of the $G 9 a D k k 3$

\section{CKO retina}

To investigate the cell fate determination and differentiation of each retinal cell type, we performed immunohistochemistry using 

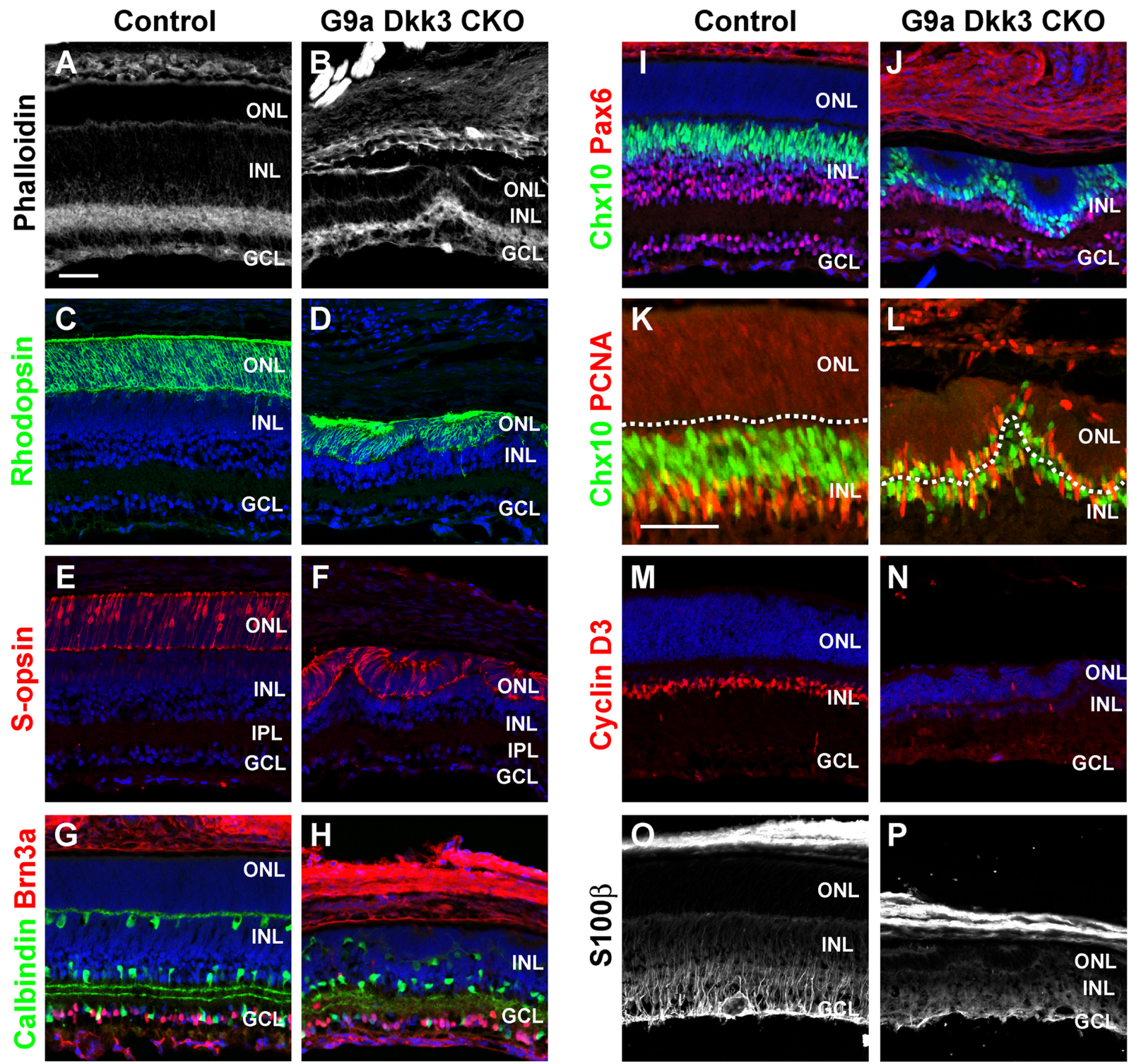

Figure 6. Retinal differentiation in the P5-P7 G9a Dkk3 CKO retina. $A-P$, Retinal sections of control $(\boldsymbol{A}, \boldsymbol{C}, \boldsymbol{E}, \mathbf{G}, \boldsymbol{I}, \boldsymbol{K}, \boldsymbol{M}, \mathbf{0})$ and $G 9 a \mathrm{Dkk} 3 \mathrm{CKO}(\boldsymbol{B}, \boldsymbol{D}, \boldsymbol{F}, \boldsymbol{H}, J, L, N, \boldsymbol{P})$ at $P 5$ were stained with markers for phalloidin $(\boldsymbol{A}, \boldsymbol{B})$. Immunostaining of rods (Rhodopsin, $\boldsymbol{C}, \boldsymbol{D})$, S-cones (S-opsin, $\boldsymbol{E}, \boldsymbol{F}$ ), horizontal cells (Calbindin, $\boldsymbol{G}, \boldsymbol{H})$, amacrine cells (Pax6, $\boldsymbol{I}, \boldsymbol{J})$, ganglion cells (Brn3a, $\boldsymbol{G}, \boldsymbol{H}$; Pax6, $\boldsymbol{I}, \boldsymbol{J})$, bipolar

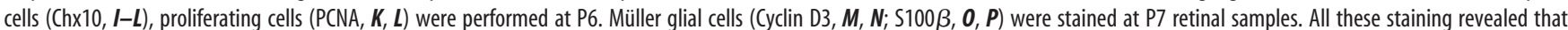
morphological abnormality already began at early postnatal stage of retinal development. Müller gliogenesis was severely affected by $G 9 a$ deficiency in retinal progenitor cells. Dotted line showed border between 0 NL and INL. Scale bars, $50 \mu \mathrm{m}$. IPL, Inner plexiform layer.

cell-type-specific marker antibodies for photoreceptor precursors (Otx2 and Crx), cone photoreceptor precursor cells ( $\operatorname{Thr} \beta 2$ ), horizontal cells (Prox1 and Lim1), amacrine cells (Pax6), ganglion cells (Brn3b), and retinal progenitor cells (Chx10 and Pax6) at E16.5. There was no significant difference in cell fate determination and cell localization of earlier generated cell types between the control and G9a Dkk3 CKO retina (Fig. $4 A-L$ ), whereas the number of apoptotic cells was higher in the retina of $G 9 a \mathrm{Dkk} 3 \mathrm{CKO}$ mice at this stage (Fig. $3 A, B$ ). These results indicate that G9a at least does not play a significant role in cell fate determination of early generated cell types.

We next examined retinas from early postnatal pups to determine when morphological abnormalities become significant. At $\mathrm{P} 1$, we found that retinal thickness was slightly reduced in the G9a Dkk3 CKO retina, consistent with markedly elevated cell death (Fig. $5 A-N)$. We also observed that localization of each retinal cell type was almost normal, except for $\mathrm{S}$-opsin ${ }^{+}$differ- entiating cells and horizontal cells (Fig. 5A-N). The numbers of Recoverin $^{+}\left(33.0 \pm 5.2\right.$ vs $18.7 \pm 3.0$ Recoverin $^{+}$cells $/ 100 \mu \mathrm{m}$ retina, $n=3 ; p=4.3 \mathrm{e}-05)$, S-opsin ${ }^{+}(36.4 \pm 6.7$ vs $12.5 \pm 2.6$ S-opsin ${ }^{+}$cells/100 $\mu \mathrm{m}$ retina, $\left.n=3 ; p=3.6 \mathrm{e}-06\right)$, and Calbin$\operatorname{din}^{+}$(horizontal cells) cells $\left(4.1 \pm 0.7\right.$ vs $2.3 \pm 0.1$ Calbindin $^{+}$ cells/ $100 \mu \mathrm{m}$ retina, $n=3 ; p=0.01$ ) decreased in the G9a Dkk3 CKO retina (Fig. 5O). These results suggest that delayed differentiation and/or cell death of differentiating cells producing photoreceptors and horizontal cells occurs in the G9a Dkk3 CKO retina at $\mathrm{P} 1$.

At $\mathrm{P} 5$ and $\mathrm{P} 6$, rosette structures were observed in the ONL of the $G 9 a$ Dkk3 CKO retina (Fig. $6 B, D, F, H, J, L$ ). At P6, we could not detect a developmental delay in photoreceptor and horizontal cells (Fig. $6 \mathrm{C}-\mathrm{H}$ ). Notably, we found that $\mathrm{Ch} \times 10^{+}$cells were ectopically localized at the inner part of the ONL (Fig. 6I,J). Because Chx10 is known to be expressed in both bipolar cells and progenitor cells, we next double immunostained the retina for 
Chx10 and PCNA. PCNA and Chx10 colocalized in some cells but not others (Fig. $6 \mathrm{~K}, L$ ), indicating that, in addition to proliferating cells, bipolar cells also ectopically localized in the ONL in the G9a Dkk3 CKO retina. Because Müller glial cells were detected after P7 in the G9a Dkk3 CKO retina, we immunostained the retina for Cyclin D3 and $S 100 \beta$ at P7. Intriguingly, Müller glial cell numbers were greatly decreased in the G9a Dkk3 CKO retina (Fig. $6 M-P$ ). These results suggest that G9a is required for proper timing of retinal differentiation and Müller gliogenesis.

G9a function in retinal progenitors is critical for proper retinal development Next, to elucidate G9a functions in cell differentiation, we focused on photoreceptors, which constitute $>70 \%$ of total retinal cells, because of the availability of the Crx-Cre mouse line in which Cre is expressed predominantly in photoreceptor precursors (Furukawa et al., 2002; Omori et al., 2012). We generated $G 9 a^{f l o x /}$ flox/Crx-Cre ${ }^{+}$(G9a Crx CKO) mice by mating $G 9 a^{\text {flox/flox }}$ mice with $G 9 a^{+/ f l o x} /$ $\mathrm{Cr} x-\mathrm{Cre}^{+}$mice. Interestingly, the $\mathrm{G} 9 \mathrm{a} \mathrm{Crx}$ CKO retina only showed a slight morphological abnormality in the ONL (Fig. 7A$F$ ), and we did not detect any rosette structure or decrease of the ONL. We then examined $\mathrm{H} 3 \mathrm{~K} 9 \mathrm{me} 2$ states in the G9a Crx $\mathrm{CKO}$ and control retina. We detected a reduced H3K9me2 signal in the G9a Crx CKO retina, whereas in the G9a Dkk3 $\mathrm{CKO}$ retina, the $\mathrm{H} 3 \mathrm{~K} 9 \mathrm{me} 2$ signal was severely reduced (Fig. 7G,I). These results indicate that G9a function in retinal progenitor cells is critical for normal retinal development, including proper cell proliferation, cell survival, and formation of retinal morphology.

Furthermore, considering that the H3K9me2 level was significantly reduced in the G9a Crx CKO retina, we assumed that G9a also plays a role in photoreceptor maintenance in mature photoreceptor cells. To determine whether $\mathrm{H} 3 \mathrm{~K} 9 \mathrm{me} 2$ modification in postmitotic cells is important for photoreceptor maintenance, we investigated the 3-month-old G9a Crx CKO retina by toluidine blue staining. We observed that the ONL became thinner in 3-month-old G9a Crx CKO mice compared with that in the control retina (Fig. $7 H-I^{\prime}$ ). Concomitant with the photoreceptor degeneration, the INL also exhibited cellular loss. The degree of degeneration was variable in that part of the retina (Fig. 7I,I'). These results suggest that $\mathrm{H} 3 \mathrm{~K} 9 \mathrm{me} 2$ mediated by G9a is also important for the survival of differentiated photoreceptor cells.

Progenitor cell-related genes were upregulated in the G9adeficient retina

To identify the genes regulated by G9a, we performed a microarray analysis. This study of mRNA expression in the G9a Dkk3 $\mathrm{CKO}$ retinas at $\mathrm{P} 6$ revealed significantly increased expression levels of 189 probes (signal log ratio, $\geq 1.0$; signal intensity, $\geq 100$ ) in
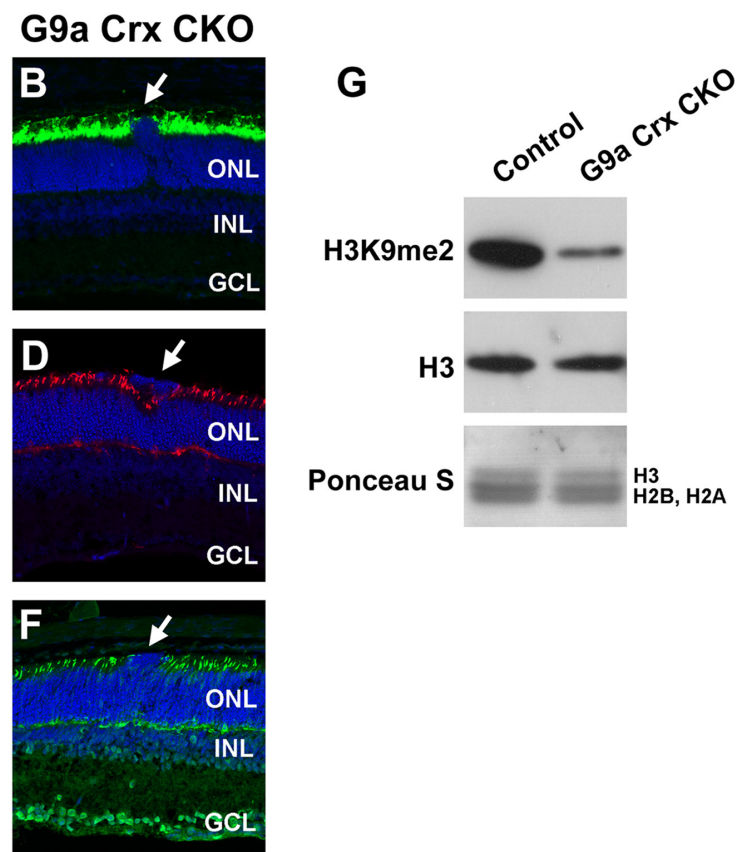

Control
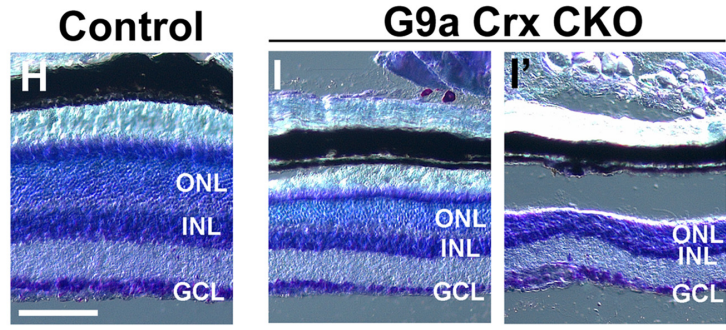

G9a Crx CKO

Rod and cone photoreceptor development in the $G 9 a$ Crx CKO retina. $\boldsymbol{A}-\boldsymbol{F}$, Sections at P14 of control $(\boldsymbol{A}, \boldsymbol{C}, \boldsymbol{E})$ and $G 9 a$ anti-H3K9me2 antibody. The amount of histone H3 was precalibrated with anti-H3 antibody and Ponceau S staining. $\boldsymbol{H}-\boldsymbol{I}^{\prime}$, Light-microscopic photographs of the toluidine blue-stained sections of adult retinas. The control retina $(\boldsymbol{H})$ and the $\mathrm{G9a} \mathrm{Crx} \mathrm{CKO}$ retina show variable degrees of degeneration in the retina (I, mild degeneration; $\boldsymbol{I}^{\prime}$, severe degeneration). Scale bars, $100 \mu \mathrm{m}$.

the G9a Dkk3 CKO retina (the list of top 35 probes in the group is shown in Table 2). We found that a loss of G9a resulted in upregulation of progenitor cell-related genes. It was reported that differentiating photoreceptors improperly expressing progenitor cell-related genes undergo apoptosis (Lin et al., 2001; Skapek et al., 2001; Sanuki et al., 2011). We confirmed the increase of progenitor cell-related genes by Q-PCR analysis (Fig. 8A). Progenitor cell-related genes were significantly increased in the G9a Dkk3 $\mathrm{CKO}$ retina. We further investigated $\mathrm{H} 3 \mathrm{~K} 9 \mathrm{me} 2$ patterns on the promoter regions of progenitor-related genes: Ccnbl, Hesl, Cond1, Chx10, and Lhx2 (Fig. 8B,C). The ChIP analysis of WT mouse retinal extracts demonstrated that $\mathrm{H} 3 \mathrm{~K} 9 \mathrm{me} 2$ was enriched in the promoters of progenitor-related genes (Fig. $8 \mathrm{~B}$ ). As in the Western blot analysis, $\mathrm{H} 3 \mathrm{~K} 9 \mathrm{me} 2$ levels strongly decreased in the G9a Dkk3 CKO retina (Fig. $8 C$ ). Notably, H3K9me2 marks on the promoters of progenitor cell-related genes were also detected in the P21 retina, but the level of $\mathrm{H} 3 \mathrm{~K} 9 \mathrm{me} 2$ was higher than in the P4 retina (Fig. 8B,C). These results suggest that H3K9me2 marks, once established on progenitor cell-related genes, are stable and persist for a long time and permanently repress improper genes. Moreover, our results also suggest that the first step of $\mathrm{H} 3 \mathrm{~K} 9 \mathrm{me} 2$ modification, mediated by G9a on the promoter of progenitor cell-related genes in retinal progenitor 
Table 2. Increased genes in the G9a Dkk3 CKO retina at P6

\begin{tabular}{|c|c|c|c|c|c|}
\hline Probe set ID & Gene symbol & Name & P6 control & P6 CK0 & Fold change \\
\hline 10466606 & Anxa 1 & Annexin A1 & 78.8 & 645.0 & 8.2 \\
\hline 10606820 & 1700008I05Rik & RIKEN CDNA 1700008105 gene & 28.8 & 145.6 & 5.1 \\
\hline 10605874 & $\mathrm{Eda} 2 \mathrm{r}$ & Ectodysplasin A2 isoform receptor & 50.2 & 225.3 & 4.5 \\
\hline 10485745 & Ano3 & Anoctamin 3 & 35.1 & 138.5 & 3.9 \\
\hline 10515836 & Ccnb1 & Cyclin B1, mRNA & 168.2 & 637.4 & 3.8 \\
\hline 10443463 & Cdkn1a (p18) & Cyclin-dependent kinase inhibitor $1 \mathrm{~A}$ & 726.7 & 2598.2 & 3.6 \\
\hline 10485624 & Prrg4 & Proline-rich Gla (G-carboxyglutamic acid) 4 (transmembrane) & 77.6 & 275.0 & 3.5 \\
\hline 10522827 & Csn1s1 & Casein $\alpha$ s1 & 36.0 & 125.9 & 3.5 \\
\hline 10390707 & Top2a & Topoisomerase (DNA) \| $\alpha$ & 194.5 & 663.8 & 3.4 \\
\hline 10409994 & EG435366 & Predicted gene 5665 & 58.1 & 196.2 & 3.4 \\
\hline 10368021 & Gje1 & Gap junction protein, $\epsilon 1$ & 438.4 & 1452.5 & 3.3 \\
\hline 10461979 & Aldh1a1 & Aldehyde dehydrogenase family 1, subfamily A1 & 467.6 & 1542.8 & 3.3 \\
\hline 10568714 & Mki67 & Antigen identified by monoclonal antibody Ki 67 & 524.0 & 1728.1 & 3.3 \\
\hline 10522895 & Csn3 & Casein $\kappa$ & 69.2 & 220.6 & 3.2 \\
\hline 10530854 & Srd5a212 & Steroid $5 \alpha$-reductase 2-like 2 & 78.6 & 248.8 & 3.2 \\
\hline 10411739 & Ccnb1 & Cyclin B1 (Ccnb1) & 231.6 & 717.7 & 3.1 \\
\hline 10466728 & 1700028P14Rik & RIKEN CDNA 1700008105 gene & 43.4 & 133.4 & 3.1 \\
\hline 10484488 & $\mathrm{P} 2 \mathrm{rx3}$ & Purinergic receptor P2X, ligand-gated ion channel, 3 & 178.3 & 537.8 & 3.0 \\
\hline 10562637 & Ccnb1 & Cyclin B1, mRNA & 292.6 & 866.2 & 3.0 \\
\hline 10487480 & Bub1 & Budding uninhibited by benzimidazoles 1 homolog (S. cerevisiae) & 169.6 & 492.3 & 2.9 \\
\hline 10497520 & Ect2 & ect2 oncogene & 342.0 & 970.2 & 2.8 \\
\hline 10429064 & Hhla1 & HERV-H LTR-associating 1 & 87.4 & 244.6 & 2.8 \\
\hline 10596737 & Gnat1 & Guanine nucleotide binding protein, $\alpha$ transducing 1 & 1580.6 & 4379.7 & 2.8 \\
\hline 10462796 & Kif11 & Kinesin family member 11 & 247.3 & 683.1 & 2.8 \\
\hline 10594251 & Kif23 & Kinesin family member 23 & 189.0 & 519.4 & 2.7 \\
\hline 10474984 & Nusap1 & Nucleolar and spindle associated protein 1 & 174.9 & 474.6 & 2.7 \\
\hline 10433172 & Glycam1 & Glycosylation-dependent cell adhesion molecule 1 & 103.8 & 279.1 & 2.7 \\
\hline 10397763 & 9030617003Rik & RIKEN cDNA 9030617003 gene & 179.8 & 480.2 & 2.7 \\
\hline 10586448 & 2810417H13Rik & RIKEN cDNA 2810417H13 gene & 181.8 & 476.2 & 2.6 \\
\hline 10404063 & Hist1h2ab & Histone cluster 1, H2ab & 74.8 & 195.8 & 2.6 \\
\hline 10400589 & Mis18bp1 & MIS18 binding protein 1 & 100.4 & 262.4 & 2.6 \\
\hline 10511939 & Spaca1 & Sperm acrosome associated 1 & 54.9 & 141.7 & 2.6 \\
\hline 10383756 & Ifitm2 & Interferon induced transmembrane protein 2 & 639.7 & 1646.7 & 2.6 \\
\hline 10461391 & Pena & Proliferating cell nuclear antigen & 983.8 & 2513.3 & 2.6 \\
\hline 10487930 & Pcna & Proliferating cell nuclear antigen & 1056.0 & 2697.8 & 2.6 \\
\hline
\end{tabular}

A direct comparison between transcripts from P6 control $(n=3)$ and G9a Dkk3 CKO retinas ( $n=3)$ were analyzed by microarray for differentially expressed RNAs. The top 35 probes showing significant upregulation in the G9a Dkk3 CKO retinas compared with controls are listed with probe set identification number (ID), gene symbol, gene name, expression level, and fold change.

cells, was weak but critical for the normal development of retinal cells, and the second step of H3K9me2 modification in postmitotic cells was strong and important for cell survival.

\section{Discussion}

Our previous study reported that the transcription factor Blimp1 stabilizes photoreceptor cell fate by repressing cell cycle- and bipolar-related genes, although Blimp1 expression decreases as photoreceptor maturation proceeds (Katoh et al., 2010). How do photoreceptors remember this repressed state continuously throughout life? The mechanisms that underlie long-term or permanent silencing in differentiating and differentiated neurons remain unclear. It is assumed that chromatin modifications (e.g., DNA methylation, histone modifications, replacement of histone variants, Polycomb group and Trithorax group proteins) are used as an epigenetic memory, which allows cells to maintain their identity permanently ( $\mathrm{Ng}$ and Gurdon, 2008), even when exposed to extracellular environments that induce other cell fates. These signatures are written on the genes without altering the genetic code itself (Mellor et al., 2008). However, changes in these signatures, which attract or repel other molecules that are the building blocks our bodies need to develop, differentiate, and maintain the function, can have an effect on physical and mental health for a lifetime (Das et al., 2009). For example, the REST (RE1 silencing transcription factor, also called NRSF for neuron- restrictive silencing factor) complex regulates the transition from transient transcriptional silencing to long-lasting silencing of neuron-specific genes through DNA methylation and histone methylation/demethylation in non-neuronal terminally differentiated cells (Ballas et al., 2005). Therefore, in the adult brain, REST shows low levels of expression (Palm et al., 1998). Aberrant expression of REST target genes are closely related to diseases, such as epilepsy (Spencer et al., 2006), ischemia (Calderone et al., 2003), Huntington disease (Zuccato et al., 2003), Down's syndrome (Bahn et al., 2002), and X-linked mental retardation (Tahiliani et al., 2007). Nevertheless, how the expression of improper genes is permanently silenced in developing and mature retinal neurons is unknown.

In our current study, we focused on G9a histone methyltransferase, because G9a expression is substantially higher in the retinal differentiation among epigenetic factors. Our immunohistochemical analysis indicated that severe retinal disorganization was detected in the G9a Dkk3 CKO retina, and this phenotype resulted from multiple abnormalities. We found that severe morphological abnormalities, including photoreceptor rosettes, drastically elevated cell death, prolonged proliferation, and mislocalization of retinal progenitors. Although cell fate determination of at least early generated retinal cell types is unaffected, we observed that cell differentiation was delayed or/and 
perturbed in other retinal cells. In addition, we detected abnormal timing of cell proliferation or/and mislocalized progenitor cells. These results suggest that G9a functions in retinal progenitor cells to orchestrate proper retinal development, although it is unclear how each abnormality relates to the others.

In the microarray and Q-PCR analyses to compare gene expression between the control and G9a Dkk3 CKO retinas at P6, we detected a significant increase in progenitor cell-related genes (cyclins, Top2a, Mki67, Bub1, PNCA, Hes1, Chx10, Ngn2, $L h \times 2$, and so on) in the G9a Dkk3 CKO retina (Fig. 8A, Table 2). Detailed examination using ChIP analysis showed $\mathrm{H} 3 \mathrm{~K} 9 \mathrm{me} 2$ enrichments in at least some of the progenitor cell-related genes (Fig. $8 B, C)$. These results partially correlate with the report by Schaefer et al. (2009). They showed that G9a deficiency in adult dopaminergic neurons leads to neuronintrinsic expression of non-neuronal and neuronal progenitor genes. Expression of non-neuronal and neuronal progenitor proteins in differentiating retinal neurons possibly induces cell death, proliferation defects, and/or delayed differentiation. Moreover, an uncontrolled state of progenitor cell-related genes in retinal progenitors may disturb the intracellular balance of progenitor cells. We also confirmed that $\mathrm{H} 3 \mathrm{~K} 9 \mathrm{me} 2$ levels increased along with cell differentiation by ChIP analysis. This result correlates well with the report that G9amediated $\mathrm{H} 3 \mathrm{~K} 9 \mathrm{me} 2$ increased along with retinal development (Wen et al., 2009; Peric-Hupkes et al., 2010; McDonald et al., 2011).

Contrary to these, the G9a Crx CKO retina, in which G9a is ablated specifically in photoreceptor precursor cells, showed almost normal differentiation, whereas the total H3K9me2 level was substantially reduced. We examined whether G9a is important at the transition point from progenitor to postmitotic retinal cell. For this purpose, we electroporated WT G9a and GFP vectors into WT mouse retinas at P0. The study by Matsuda and Cepko (2004) showed that electroporated vectors are mainly introduced in retinal progenitor cells. We harvested the electroporated retinas at P6. The harvested retinas showed almost normal development (data not shown), suggesting that H3K9me2 mark is probably necessary for differentiation rather than to provide the spark for transition from progenitor cells to postmitotic cells. These results suggest that, once $\mathrm{H} 3 \mathrm{~K} 9 \mathrm{me} 2$ marks are established on the promoters of proper genes in retinal progenitor cells, G9a activity at least in photoreceptor precursors is no longer essential for cell differentiation or maturation. At the same time, it should be noted that G9a function in postmitotic cells is important for maintenance of differentiated cells. Thus, the establishment of $\mathrm{H} 3 \mathrm{~K} 9 \mathrm{me} 2$ marks in retinal progenitor cells is crucial for normal development and appears to serve as an epigenetic memory of the differentiated state. In retinal progenitor cells, progenitor cell-related genes may be poised for transcriptional repression via the $\mathrm{H} 3 \mathrm{~K} 9$ me 2 mark mediated by G9a, and this mark probably functions in differentiating cells. Consistent with this, it was reported that the chromatin prepatterning of modified histones has an instructive role in proper fate determination and later development in zebrafish fertilized eggs before zygotic gene activation and also in mouse embryonic endoderm cells (Lindeman et al., 2011; Xu et al., 2011). Moreover, in embryonic stem cells, some developmental genes are present within bivalent chromatin regions of both $\mathrm{H} 3 \mathrm{~K} 4 \mathrm{me} 3$ (active mark) and H3K27me3 (inactive mark) (Szutorisz et al., 2005; Bernstein et al., 2006). These observations suggest that, after the proper signal have been provided, these genes are automatically poised for transcriptional activation or repression through the histone modification. Our results suggest that $\mathrm{H} 3 \mathrm{~K} 9 \mathrm{me} 2$ marks mediated by G9a potentially serve similar functions. It should be noted that $\mathrm{H} 3 \mathrm{~K} 9 \mathrm{me} 2$ was reported to be an epigenetic mark associated with inactive promoters (Tachibana et al., 2001, 2002). However, we did not observe a significant abnormal cell cycle arrest or proliferation inhibition in retinal progenitor cells. Therefore, our results suggest that there is unknown machinery that overcomes the $\mathrm{H} 3 \mathrm{~K} 9 \mathrm{me} 2$ repressive mark in retinal progenitor cells.

How does the methylated histone mark function? It was reported that the ANK repeats of G9a bind to H3K9me2 (Collins et al., 2008). Moreover, G9a can associate with DNA methyltransferases to repress transcription in embryonic stem cells (Estève et al., 2006; Collins et al., 2008; Epsztejn-Litman et al., 2008; Tachibana et al., 2008; Leung et al., 2011). These findings raise the possibility that $\mathrm{H} 3 \mathrm{~K} 9 \mathrm{me} 2$ marks become a target of DNA methylation and are replaced by DNA methylation at later developmental stages. The DNA methylation mark is the most stable 


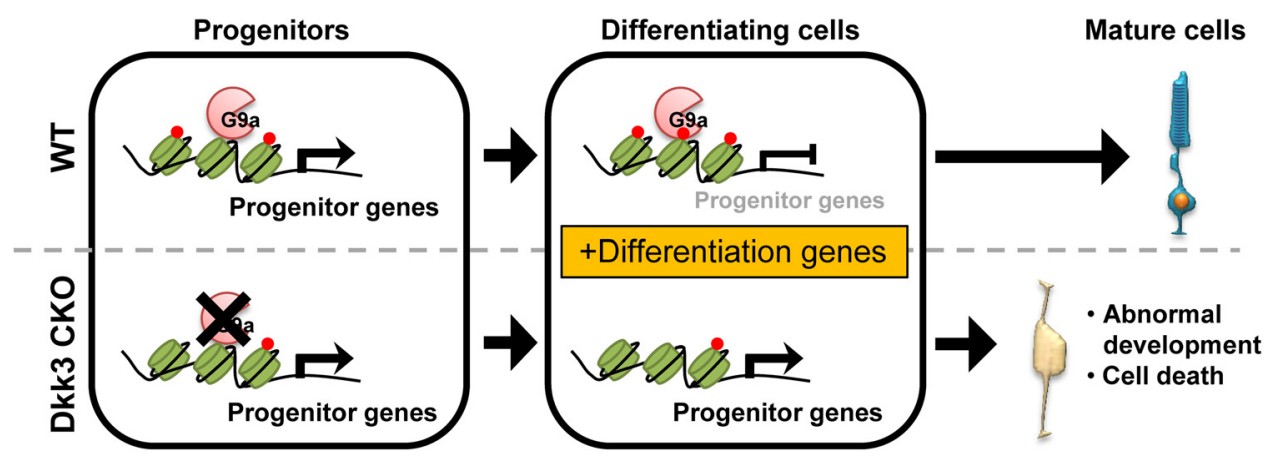

Figure 9. A hypothetical model of G9a functional mechanism. In the WT retina (top), G9a expressed in the retinal progenitor cells may mark H3K9me2 in progenitor genes and stably silence these genes. $\mathrm{G9}$ a also dimethylates $\mathrm{H3K}$ in differentiating cells, but de novo H3K9 methylation at this stage is not essential for differentiation. Cell-type-specific genes drive the maturation of retinal cells. In the G9a Dkk3 CKO retina (bottom), lack of H3K9me2 marks result in abnormal expression of progenitor-related genes and lead to the impaired integrity of progenitor cells, cell death, and abnormal development of retinal cells.

epigenetic mark and plays an important role in epigenetic memory (Ji et al., 2010; Kim et al., 2010). G9a probably induces DNA methyltransferases to bind $\mathrm{H} 3 \mathrm{~K} 9 \mathrm{me} 2$ in the differentiating/differentiated retinal cells, and necessary DNA methylation on the promoter of proper genes may not be induced in progenitors of the $G 9 a$ depleted retina. In other words, $\mathrm{H} 3 \mathrm{~K} 9 \mathrm{me} 2$ mediated by G9a in retinal progenitor cells may function to prepare the epigenetic memory for the differentiated state, whereas the subsequent DNA methylation in differentiating/differentiated neurons may ensure this state. Because this ensuring step is assumed to be defective in the $\mathrm{G} 9 \mathrm{a} \mathrm{Cr} x$ CKO retina, mature photoreceptor cells would degenerate. Consistent with this, we found that the expression of a DNA methyltransferase Dnmt3a increased along with retinal development in our microarray data (Omori et al., 2011). Moreover, Nasonkin et al. (2011) and mouse retina SAGE library data (http://cepko.med. harvard.edu/) also showed that DNA methyltransferases are expressed in the adult retina. A future study on DNA methylation in the G9a Dkk3 CKO retina is required to reveal whether H3K9me2 marks on the promoters of proper genes induce DNA methylation or not.

In summary, our findings demonstrate that the H3K9me2 histone modification mediated by G9a before differentiation in progenitor cells is essential for proper differentiation of postmitotic cells and integrity of retinal progenitor cells in the mouse retina. Moreover, G9a deletion in differentiating photoreceptor cells results in retinal degeneration. Our observation suggests that $\mathrm{H} 3 \mathrm{~K} 9 \mathrm{me} 2$ mediated by G9a serves as an epigenetic memory in the differentiated state (Fig. 9). Future investigation of G9a- and H3K9me2-associated molecules including Blimp1 (Gyory et al., 2004) may reveal the in vivo mechanism of how histone methylation marks are written, recognized, and read out during retinal development.

\section{References}

Bahn S, Mimmack M, Ryan M, Caldwell MA, Jauniaux E, Starkey M, Svendsen CN, Emson P (2002) Neuronal target genes of the neuron-restrictive silencer factor in neurospheres derived from fetuses with Down's syndrome: a gene expression study. Lancet 359:310-315. CrossRef Medline

Ballas N, Grunseich C, Lu DD, Speh JC, Mandel G (2005) REST and its corepressors mediate plasticity of neuronal gene chromatin throughout neurogenesis. Cell 121:645-657. CrossRef Medline

Berger SL, Kouzarides T, Shiekhattar R, Shilatifard A (2009) An operational definition of epigenetics. Genes Dev 23:781-783. CrossRef Medline

Bernstein BE, Mikkelsen TS, Xie X, Kamal M, Huebert DJ, Cuff J, Fry B, Meissner A, Wernig M, Plath K, Jaenisch R, Wagschal A, Feil R, Schreiber SL, Lander ES (2006) A bivalent chromatin structure marks key developmental genes in embryonic stem cells. Cell 125:315-326. CrossRef Medline

Black GC, Mazerolle CJ, Wang Y, Campsall KD, Petrin D, Leonard BC, Damji
KF, Evans DG, McLeod D, Wallace VA (2003) Abnormalities of the vitreoretinal interface caused by dysregulated Hedgehog signaling during retinal development. Hum Mol Genet 12:3269-3276. CrossRef Medline

Calderone A, Jover T, Noh KM, Tanaka H, Yokota H, Lin Y, Grooms SY, Regis R, Bennett MV, Zukin RS (2003) Ischemic insults derepress the gene silencer REST in neurons destined to die. J Neurosci 23:2112-2121. Medline

Cepko CL (1996) The patterning and onset of opsin expression in vertebrate retinae. Curr Opin Neurobiol 6:542-546. CrossRef Medline

Cheung P, Tanner KG, Cheung WL, Sassone-Corsi P, Denu JM, Allis CD (2000) Synergistic coupling of histone H3 phosphorylation and acetylation in response to epidermal growth factor stimulation. Mol Cell 5:905915. CrossRef Medline

Collins RE, Northrop JP, Horton JR, Lee DY, Zhang X, Stallcup MR, Cheng X (2008) The ankyrin repeats of G9a and GLP histone methyltransferases are mono- and dimethyllysine binding modules. Nat Struct Mol Biol 15:245-250. CrossRef Medline

Damiani D, Alexander JJ, O'Rourke JR, McManus M, Jadhav AP, Cepko CL, Hauswirth WW, Harfe BD, Strettoi E (2008) Dicer inactivation leads to progressive functional and structural degeneration of the mouse retina. J Neurosci 28:4878-4887. CrossRef Medline

Das R, Hampton DD, Jirtle RL (2009) Imprinting evolution and human health. Mamm Genome 20:563-572. CrossRef Medline

Dyer MA, Cepko CL (2000) Control of Muller glial cell proliferation and activation following retinal injury. Nat Neurosci 3:873-880. CrossRef Medline

Epsztejn-Litman S, Feldman N, Abu-Remaileh M, Shufaro Y, Gerson A, Ueda J, Deplus R, Fuks F, Shinkai Y, Cedar H, Bergman Y (2008) De novo DNA methylation promoted by G9a prevents reprogramming of embryonically silenced genes. Nat Struct Mol Biol 15:1176-1183. CrossRef Medline

Estève PO, Chin HG, Smallwood A, Feehery GR, Gangisetty O, Karpf AR, Carey MF, Pradhan S (2006) Direct interaction between DNMT1 and G9a coordinates DNA and histone methylation during replication. Genes Dev 20:3089-3103. CrossRef Medline

Furukawa A, Koike C, Lippincott P, Cepko CL, Furukawa T (2002) The mouse Crx 5'-upstream transgene sequence directs cell-specific and developmentally regulated expression in retinal photoreceptor cells. J Neurosci 22:1640-1647. Medline

Gyory I, Wu J, Fejér G, Seto E, Wright KL (2004) PRDI-BF1 recruits the histone $\mathrm{H} 3$ methyltransferase G9a in transcriptional silencing. Nat Immunol 5:299-308. CrossRef Medline

Ji H, Ehrlich LI, Seita J, Murakami P, Doi A, Lindau P, Lee H, Aryee MJ, Irizarry RA, Kim K, Rossi DJ, Inlay MA, Serwold T, Karsunky H, Ho L, Daley GQ, Weissman IL, Feinberg AP (2010) Comprehensive methylome map of lineage commitment from haematopoietic progenitors. Nature 467:338-342. CrossRef Medline

Katoh K, Omori Y, Onishi A, Sato S, Kondo M, Furukawa T (2010) Blimp1 suppresses Chx10 expression in differentiating retinal photoreceptor precursors to ensure proper photoreceptor development. J Neurosci 30: 6515-6526. CrossRef Medline

Kim K, Doi A, Wen B, Ng K, Zhao R, Cahan P, Kim J, Aryee MJ, Ji H, Ehrlich 
LI, Yabuuchi A, Takeuchi A, Cunniff KC, Hongguang H, McKinneyFreeman S, Naveiras O, Yoon TJ, Irizarry RA, Jung N, Seita J, Hanna J, Murakami P, Jaenisch R, Weissleder R, Orkin SH, Weissman IL, Feinberg AP, Daley GQ (2010) Epigenetic memory in induced pluripotent stem cells. Nature 467:285-290. CrossRef Medline

Koike C, Nishida A, Ueno S, Saito H, Sanuki R, Sato S, Furukawa A, Aizawa S, Matsuo I, Suzuki N, Kondo M, Furukawa T (2007) Functional roles of Otx2 transcription factor in postnatal mouse retinal development. Mol Cell Biol 27:8318-8329. CrossRef Medline

Kubicek S, O'Sullivan RJ, August EM, Hickey ER, Zhang Q, Teodoro ML, Rea S, Mechtler K, Kowalski JA, Homon CA, Kelly TA, Jenuwein T (2007) Reversal of H3K9me2 by a small-molecule inhibitor for the G9a histone methyltransferase. Mol Cell 25:473-481. CrossRef Medline

Lahav M, Albert DM, Craft JL (1975) Light and electron microscopic study of dysplastic rosette-like structures occurring in the disorganized mature retina. Albrecht Von Graefes Arch Klin Exp Ophthalmol 195:57-68. CrossRef Medline

Lehnertz B, Northrop JP, Antignano F, Burrows K, Hadidi S, Mullaly SC, Rossi FM, Zaph C (2010) Activating and inhibitory functions for the histone lysine methyltransferase G9a in T helper cell differentiation and function. J Exp Med 207:915-922. CrossRef Medline

Leung DC, Dong KB, Maksakova IA, Goyal P, Appanah R, Lee S, Tachibana M, Shinkai Y, Lehnertz B, Mager DL, Rossi F, Lorincz MC (2011) Lysine methyltransferase G9a is required for de novo DNA methylation and the establishment, but not the maintenance, of proviral silencing. Proc Natl Acad Sci U S A 108:5718-5723. CrossRef Medline

Lin SC, Skapek SX, Papermaster DS, Hankin M, Lee EY (2001) The proliferative and apoptotic activities of E2F1 in the mouse retina. Oncogene 20:7073-7084. CrossRef Medline

Lindeman LC, Andersen IS, Reiner AH, Li N, Aanes H, Østrup O, Winata C, Mathavan S, Müller F, Aleström P, Collas P (2011) Prepatterning of developmental gene expression by modified histones before zygotic genome activation. Dev Cell 21:993-1004. CrossRef Medline

Matsuda T, Cepko CL (2004) Electroporation and RNA interference in the rodent retina in vivo and in vitro. Proc Natl Acad Sci U S A 101:16-22. CrossRef Medline

McDonald OG, Wu H, Timp W, Doi A, Feinberg AP (2011) Genome-scale epigenetic reprogramming during epithelial-to-mesenchymal transition. Nat Struct Mol Biol 18:867-874. CrossRef Medline

Mears AJ, Kondo M, Swain PK, Takada Y, Bush RA, Saunders TL, Sieving PA, Swaroop A (2001) Nrl is required for rod photoreceptor development. Nat Genet 29:447-452. CrossRef Medline

Mellor J, Dudek P, Clynes D (2008) A glimpse into the epigenetic landscape of gene regulation. Curr Opin Genet Dev 18:116-122. CrossRef Medline

Mohn F, Schübeler D (2009) Genetics and epigenetics: stability and plasticity during cellular differentiation. Trends Genet 25:129-136. CrossRef Medline

Mongan M, Wang J, Liu H, Fan Y, Jin C, Kao WY, Xia Y (2011) Loss of MAP3K1 enhances proliferation and apoptosis during retinal development. Development 138:4001-4012. CrossRef Medline

Nasonkin IO, Lazo K, Hambright D, Brooks M, Fariss R, Swaroop A (2011) Distinct nuclear localization patterns of DNA methyltransferases in developing and mature mammalian retina. J Comp Neurol 519:1914-1930. CrossRef Medline

Ng RK, Gurdon JB (2008) Epigenetic inheritance of cell differentiation status. Cell Cycle 7:1173-1177. CrossRef Medline

Omori Y, Katoh K, Sato S, Muranishi Y, Chaya T, Onishi A, Minami T, Fujikado T, Furukawa T (2011) Analysis of transcriptional regulatory pathways of photoreceptor genes by expression profiling of the Otx2deficient retina. PLoS One 6:e19685. CrossRef Medline

Omori Y, Araki F, Chaya T, Kajimura N, Irie S, Terada K, Muranishi Y, Tsujii T, Ueno S, Koyasu T, Tamaki Y, Kondo M, Amano S, Furukawa T (2012) Presynaptic dystroglycan-pikachurin complex regulates the proper synaptic connection between retinal photoreceptor and bipolar cells. J Neurosci 32:6126-6137.

Palm K, Belluardo N, Metsis M, Timmusk T (1998) Neuronal expression of zinc finger transcription factor REST/NRSF/XBR gene. J Neurosci 18: 1280-1296. Medline

Peric-Hupkes D, Meuleman W, Pagie L, Bruggeman SW, Solovei I, Brugman W, Gräf S, Flicek P, Kerkhoven RM, van Lohuizen M, Reinders M, Wessels L, van Steensel B (2010) Molecular maps of the reorganization of genome-nuclear lamina interactions during differentiation. Mol Cell 38: 603-613. CrossRef Medline

Peters AH, Kubicek S, Mechtler K, O’Sullivan RJ, Derijck AA, Perez-Burgos L, Kohlmaier A, Opravil S, Tachibana M, Shinkai Y, Martens JH, Jenuwein T (2003) Partitioning and plasticity of repressive histone methylation states in mammalian chromatin. Mol Cell 12:1577-1589. CrossRef Medline

Ptashne M (2007) On the use of the word "epigenetic." Curr Biol 17:R233R236. CrossRef Medline

Reik W (2007) Stability and flexibility of epigenetic gene regulation in mammalian development. Nature 447:425-432. CrossRef Medline

Rice JC, Briggs SD, Ueberheide B, Barber CM, Shabanowitz J, Hunt DF, Shinkai Y, Allis CD (2003) Histone methyltransferases direct different degrees of methylation to define distinct chromatin domains. Mol Cell 12:1591-1598. CrossRef Medline

Riesenberg AN, Liu Z, Kopan R, Brown NL (2009) Rbpj cell autonomous regulation of retinal ganglion cell and cone photoreceptor fates in the mouse retina. J Neurosci 29:12865-12877. CrossRef Medline

Sanuki R, Onishi A, Koike C, Muramatsu R, Watanabe S, Muranishi Y, Irie S, Uneo S, Koyasu T, Matsui R, Chérasse Y, Urade Y, Watanabe D, Kondo M, Yamashita T, Furukawa T (2011) miR-124a is required for hippocampal axogenesis and retinal cone survival through Lhx2 suppression. Nat Neurosci 14:1125-1134. CrossRef Medline

Sato S, Inoue T, Terada K, Matsuo I, Aizawa S, Tano Y, Fujikado T, Furukawa $\mathrm{T}$ (2007) Dkk3-Cre BAC transgenic mouse line: a tool for highly efficient gene deletion in retinal progenitor cells. Genesis 45:502-507. CrossRef Medline

Schaefer A, Sampath SC, Intrator A, Min A, Gertler TS, Surmeier DJ, Tarakhovsky A, Greengard P (2009) Control of cognition and adaptive behavior by the GLP/G9a epigenetic suppressor complex. Neuron 64:678-691. CrossRef Medline

Shi Y, Desponts C, Do JT, Hahm HS, Schöler HR, Ding S (2008) Induction of pluripotent stem cells from mouse embryonic fibroblasts by Oct4 and Klf4 with small-molecule compounds. Cell Stem Cell 3:568-574. CrossRef Medline

Skapek SX, Lin SC, Jablonski MM, McKeller RN, Tan M, Hu N, Lee EY (2001) Persistent expression of cyclin D1 disrupts normal photoreceptor differentiation and retina development. Oncogene 20:6742-6751. CrossRef Medline

Spencer EM, Chandler KE, Haddley K, Howard MR, Hughes D, Belyaev ND, Coulson JM, Stewart JP, Buckley NJ, Kipar A, Walker MC, Quinn JP (2006) Regulation and role of REST and REST4 variants in modulation of gene expression in in vivo and in vitro in epilepsy models. Neurobiol Dis 24:41-52. CrossRef Medline

Szutorisz H, Canzonetta C, Georgiou A, Chow CM, Tora L, Dillon N (2005) Formation of an active tissue-specific chromatin domain initiated by epigenetic marking at the embryonic stem cell stage. Mol Cell Biol 25:18041820. CrossRef Medline

Tachibana M, Sugimoto K, Fukushima T, Shinkai Y (2001) Set domaincontaining protein, G9a, is a novel lysine-preferring mammalian histone methyltransferase with hyperactivity and specific selectivity to lysines 9 and 27 of histone H3. J Biol Chem 276:25309-25317. CrossRef Medline

Tachibana M, Sugimoto K, Nozaki M, Ueda J, Ohta T, Ohki M, Fukuda M, Takeda N, Niida H, Kato H, Shinkai Y (2002) G9a histone methyltransferase plays a dominant role in euchromatic histone H3 lysine 9 methylation and is essential for early embryogenesis. Genes Dev 16:1779-1791. CrossRef Medline

Tachibana M, Nozaki M, Takeda N, Shinkai Y (2007) Functional dynamics of H3K9 methylation during meiotic prophase progression. EMBO J 26: 3346-3359. CrossRef Medline

Tachibana M, Matsumura Y, Fukuda M, Kimura H, Shinkai Y (2008) G9a/ GLP complexes independently mediate H3K9 and DNA methylation to silence transcription. EMBO J 27:2681-2690. CrossRef Medline

Tahiliani M, Mei P, Fang R, Leonor T, Rutenberg M, Shimizu F, Li J, Rao A, Shi Y (2007) The histone H3K4 demethylase SMCX links REST target genes to X-linked mental retardation. Nature 447:601-605. CrossRef Medline

Thomas LR, Miyashita H, Cobb RM, Pierce S, Tachibana M, Hobeika E, Reth M, Shinkai Y, Oltz EM (2008) Functional analysis of histone methyltransferase g9a in B and T lymphocytes. J Immunol 181:485-493. Medline

Tulvatana W, Adamian M, Berson EL, Dryja TP (1999) Photoreceptor ro- 
settes in autosomal dominant retinitis pigmentosa with reduced penetrance. Arch Ophthalmol 117:399-402. CrossRef Medline

Wen B, Wu H, Shinkai Y, Irizarry RA, Feinberg AP (2009) Large histone H3 lysine 9 dimethylated chromatin blocks distinguish differentiated from embryonic stem cells. Nat Genet 41:246-250. CrossRef Medline

Xu CR, Cole PA, Meyers DJ, Kormish J, Dent S, Zaret KS (2011) Chromatin "prepattern" and histone modifiers in a fate choice for liver and pancreas. Science 332:963-966. CrossRef Medline
Yuge K, Nakajima M, Uemura Y, Miki H, Uyama M, Tsubura A (1995) Immunohistochemical features of the human retina and retinoblastoma. Virchows Arch 426:571-575. CrossRef Medline

Zuccato C, Tartari M, Crotti A, Goffredo D, Valenza M, Conti L, Cataudella T, Leavitt BR, Hayden MR, Timmusk T, Rigamonti D, Cattaneo E (2003) Huntingtin interacts with REST/NRSF to modulate the transcription of NRSE-controlled neuronal genes. Nat Genet 35:76-83. CrossRef Medline 